Article

\title{
Physiological and Biochemical Behaviors of Date Palm Vitroplants Treated with Microbial Consortia and Compost in Response to Salt Stress
}

\author{
Salma Toubali ${ }^{1,2}$, Abdel-ilah Tahiri ${ }^{1,3}{ }^{(0)}$, Mohamed Anli ${ }^{1,2,3}{ }^{(D}$, Sarah Symanczik ${ }^{4}$, \\ Abderrahim Boutasknit 1,2 ${ }^{\mathbb{D}}$, Mohamed Ait-El-Mokhtar 1,2 ${ }^{1}$, Raja Ben-Laouane 1,2, \\ Khalid Oufdou ${ }^{3,5}$, Youssef Ait-Rahou ${ }^{1}$, Hela Ben-Ahmed ${ }^{2}$, Martin Jemo ${ }^{5}$, Mohamed Hafidi ${ }^{3,5}$ \\ and Abdelilah Meddich 1,2,*(D) \\ 1 Laboratory of Agro-Food, Biotechnologies and Valorization of Plant Bioresources (AGROBIOVAL), \\ Faculty of Science Semlalia, Cadi Ayyad University, P.O. Box 2390, Marrakesh, Morocco; \\ salma.toubali@edu.uca.ac.ma (S.T.); abdelilah.tahiri@edu.uca.ac.ma (A.-i.T.); \\ mohamed.anli@edu.uca.ac.ma (M.A.); abderrahim.boutasknit@edu.uca.ac.ma (A.B.); \\ mohamed.aitelmokhtar@ced.uca.ma (M.A.-E.-M.); raja.benlaouane@ced.uca.ma (R.B.-L.); \\ youssef.aitrahou@edu.uca.ac.ma (Y.A.-R.) \\ 2 Laboratoires Mixtes Tuniso-Marocain (LMTM) de Physiologie et Biotechnologie Végétales et Changements \\ Climatiques LPBV2C, Tunis 1000, Tunisia; hela.benahmed@fst.utm.tn \\ 3 Laboratory of Microbial Biotechnologies, Agrosciences and Environment (BioMAgE), \\ Faculty of Science Semlalia, Cadi Ayyad University, P.O. Box 2390, Marrakesh, Morocco; \\ oufdou@uca.ac.ma (K.O.); hafidi@uca.ac.ma (M.H.) \\ 4 Soil Science Department, Research Institute of Organic Agriculture (FiBL), Ackerstrasse 113, \\ 5070 Frick, Switzerland; sarah.symanczik@fibl.org \\ 5 Agrobiosciences Program, University Mohammed VI Polytechnic (UM6P), 43150 Ben Guerir, Morocco; \\ martin.jemo@um6p.ma \\ * Correspondence: a.meddich@uca.ma
}

Received: 20 October 2020; Accepted: 9 November 2020; Published: 3 December 2020

\begin{abstract}
The main challenge of the agricultural sector is to develop new ecological technologies that increase the yields and the tolerance of crops to abiotic constraints, especially in arid areas. The objective of this study was to test the potential roles of biofertilizers, namely, arbuscular mycorrhizal fungi $(\mathrm{AMF})$, a native $\mathrm{AMF}$ consortium $\left(\mathrm{AMF}_{1}\right)$ and an exotic $\mathrm{AMF}$ strain $\left(\mathrm{AMF}_{2}\right)$; plant growth-promoting rhizobacteria (PGPR); and compost (comp), applied separately or in combination, in improving the tolerance of date palm vitroplants to salt stress. Plants were grown under non-stressed $(0 \mathrm{mM}$ $\mathrm{NaCl}$ ) or stressed conditions (120 and $240 \mathrm{mM} \mathrm{NaCl}$ ). Salt stress negatively affected growth and physiological parameters. However, biofertilizers used alone or in combination increased these traits in either the presence or absence of salinity. The two tripartite combinations PGPR+AMF1+Comp and PGPR+AMF2+Comp efficiently increased plant height compared to the controls, with respective enhancements of $47 \%$ and $48 \%$ under non-stressed conditions $(0 \mathrm{mM}), 44 \%$ and $43 \%$ under $120 \mathrm{mM}$ $\mathrm{NaCl}$ and $42 \%$ and $41 \%$ under $240 \mathrm{mM} \mathrm{NaCl}$. Moreover, under $240 \mathrm{mM} \mathrm{NaCl}$ level, the PGPR, AMF1+Comp and PGPR+AMF1+Comp treatments improved the shoot dry weight by $128 \%, 122 \%$ and $113 \%$ respectively compared to the stressed control plants submitted to $240 \mathrm{mM} \mathrm{NaCl}$. The tripartite combinations PGPR $+\mathrm{AMF}_{1} / \mathrm{AMF}_{2}+\mathrm{Comp}$ improved salt stress tolerance of plants by increasing plant growth, accumulation of osmotic adjustment compounds and antioxidant enzyme activity compared to control plants and the other treatments.
\end{abstract}

Keywords: arbuscular mycorrhizal fungi; plant growth-promoting rhizobacteria; compost; tolerance; salt stress; date palm 


\section{Introduction}

Date palm (Phoenix dactylifera L.) is a multipurpose crop cultivated for many millennia in arid and semi-arid regions in the world mostly [1]. In Morocco, date palm covers approximately 59,000 hectares with an average production of 111,701 tons fresh of fruits in 2018 [2]. The date palm has great economic importance since it constitutes the pivot of the oasis ecosystem of the Saharan and pre-Saharan regions of Morocco, and it provides not only dates but also various materials intended for handicrafts, construction and energy production [3]. It also provides a local microclimate that promotes the development of several underlying crops, such as forage species [4]. However, date palm growth is often hampered by soil fertility and other environmental limiting factors, such as drought and soil salinity [5-8].

Soil salinity is one of the major problems for agriculture mainly in arid and semi-arid regions, which strongly affects plant growth and productivity [9]. High levels of salinity in soils lead to ion toxicity, disturbed $\mathrm{Na}^{+} / \mathrm{K}^{+}$homeostasis and enhanced production of reactive oxygen species (ROS), thereby causing oxidation of membrane lipids, protein and nucleic acids [10], growth inhibition and disruption of photosynthesis activity and productivity [11-13]. However, plants can remove generated ROS by different defense mechanisms such as the antioxidant system. The antioxidant system includes many enzymes, such as superoxide dismutase (SOD), catalase (CAT), peroxidase (POD) and polyphenol oxidase (PPO) $[14,15]$. Another protective mechanism to prevent stress damage is the storage and compartmentalization of toxic ions in specific cell compartments [16,17]. Previous studies already searched for alternatives that could increase these different defense mechanisms in plants under saline conditions. One of these alternatives is the use of biofertilizers including mycorrhizal fungi (AMF), plant growth-promoting rhizobacteria (PGPR) and compost to reduce the harmful effects of salt stress on plants $[8,10,18]$.

AMF usually form symbiotic relationships with many plants to modulate the growth of host plants grown under saline conditions by direct and indirect mechanisms, such as mitigation of ROS and oxidative damage via the mediation of phytohormone synthesis $[18,19]$, and enhancing the enzymatic and non-enzymatic antioxidant defense system [20,21]. Besides, the beneficial effects of AMF are linked to nutrient mobilization, such as that of phosphorus and other micronutrients; the use of soil organic matter; and improvements in soil structure [22-27]. Additionally, PGPR can mitigate the detrimental effects of salt stress by improving plant growth through the production of phytohormones such as indole acetic acid (IAA) [28], and the fixation of atmospheric N [29].

Furthermore, compost has been used for decades as a soil conditioner in agriculture to improve the supply of organic carbon and enhance the soil storage capacity of water and nutrients, leading to increased photosynthetic activity, yields and stress tolerance of plants [6,30-33].

The innovative approach combining compost from green waste, native PGPR and AMF has recently shown promise for assisting with alfalfa and other cultures to tolerate heavy metals and salt stress [32-34].

The objective of this work was to study the effects of compost, PGPR, AMF and their combination on growth, physiological and biochemical parameters of date palm vitroplants (var. Bouffgous) grown under salt stress. The Bouffgous variety from Morocco is a genetically stable variety multiplied by in vitro culture and presents an important economic interest because it is widely cultivated in Morocco, known for its high productivity and excellent date quality. This study aims to investigate the influence of low-dose, easy to produce, local compost in combination with PGPR and native or exotic AMF, on the tolerance of date palm vitroplants to salt stress. 


\section{Materials and Methods}

\subsection{Biological Materials}

Vitroplants (Phoenix dactylifera L.) var. Bouffegous of the two leaf growth stage were obtained by in vitro vegetative multiplication from the commercial laboratory of "Domaine Agricole El Bassatine", Meknes, Morocco.

The AMF consortium $\left(\mathrm{AMF}_{1}\right)$ was isolated from the Tafilalet palm grove $\left(31^{\circ} 47^{\prime} 20.8^{\prime \prime} \mathrm{N}\right.$ and $4^{\circ} 14^{\prime} 59.3^{\prime \prime} \mathrm{W}$ ) located at $500 \mathrm{Km}$ southeast of Marrakesh (Morocco) and contained a mixture of native species: Glomus sp. (15 spores/g of soil), Sclerocystis sp. (9 spores/g soil) and Acaulospora sp. (1 spore/g of soil) [24]. Moreover, an exotic AMF strain, Rhizophagus irregularis $\left(\mathrm{AMF}_{2}\right)$ provided by Dr. Hijri (Research Institute of Plant Biology, University of Quebec, Montreal, Canada), was used for inoculation. Corn (Zea mays L.) plants were used as a host plant to multiply both AMF inocula, which were composed of mycorrhizal root segment and AMF spores.

The bacterial inoculum consisted of two PGPR strains, Z1 and Z4 isolated from date palm rhizospheric soil collected in the Zouala region located in Tafilalet palm grove $\left(31^{\circ} 47^{\prime} 20.8^{\prime \prime} \mathrm{N}\right.$ and $\left.4^{\circ} 14^{\prime} 59.3^{\prime \prime} \mathrm{W}\right)$, Morocco. The inoculum was prepared by multiplication of the strains in trypticase soy broth (TSB) medium and shaken for 24 to $48 \mathrm{~h}$ at $28^{\circ} \mathrm{C}$ to obtain an optical density $(\mathrm{OD}=1)$ at $600 \mathrm{~nm}$ (corresponding to approximately $10^{9}$ colony-forming units (CFU) $\mathrm{mL}^{-1}$ ).

The compost used in this study was obtained from the compost unit of the Faculty of Science Semlalia, Marrakesh, Morocco. The compost was produced from green waste (Quack grass) as described by Meddich et al. [35]. The characteristics of the compost used in this study are reported in Table 1.

Table 1. Physicochemical parameters of the soil and compost.

\begin{tabular}{ccc}
\hline & Soil & Compost \\
\hline $\mathrm{pH}$ & $8.60(0.08)$ & $7.74(0.01)$ \\
$\mathrm{EC}\left(\mu \mathrm{S} \mathrm{cm}^{-2}\right)$ & $190.00(0.45)$ & $5460.00(0.20)$ \\
$\left.\mathrm{NTK}^{+} \%\right)$ & $0.11(0.01)$ & $1.32(0.01)$ \\
$\mathrm{NH}_{4}^{+}(\%)$ & - & $0.09(0.01)$ \\
$\mathrm{NO}_{3}^{-}(\%)$ & - & $0.31(0.01)$ \\
$\mathrm{TOC}(\%)$ & $0.59(0.12)$ & $5.72(0.45)$ \\
$\mathrm{OM}(\%)$ & $1.02(0.20)$ & $9.86(0.78)$ \\
$\mathrm{C} / \mathrm{N}$ & - & 7.49 \\
$\mathrm{NH}_{4}^{+} / \mathrm{NO}_{3}^{-}$ & - & 0.29 \\
$\mathrm{P}_{\mathrm{olsen}^{-}}(\mathrm{ppm})$ & $11.00(0.22)$ & $489.95(20.29)$ \\
$\mathrm{Na}^{+}(\mathrm{ppm})$ & $990.00(30.00)$ & $2110.00(50.00)$ \\
$\mathrm{K}^{+}(\mathrm{ppm})$ & $890.00(50.00)$ & $5590.00(150.00)$ \\
$\mathrm{Ca}^{2+}(\mathrm{ppm})$ & $11,480.00(480.00)$ & $37,380.00(1840.00)$ \\
\hline
\end{tabular}

EC: electrical conductivity; NTK: total Kjeldahl nitrogen; TOC: total organic carbon; OM: organic matter; C/N: ratio of carbon to nitrogen. Data presented are means (with standard deviation).

\subsection{Experimental Design and Growth Conditions}

The vitroplants were acclimatized for two months in a greenhouse with a day/night temperature of $26^{\circ} \mathrm{C}$, fluorescent lighting of $500 \mu \mathrm{molm}^{-2} \mathrm{~s}^{-1}$, a $16 / 8 \mathrm{~h}$ light/dark photoperiod and relative humidity of $68.5 \%$. After this period, each vitroplant was transferred to a $4 \mathrm{~L}$ plastic pot containing $3.5 \mathrm{~kg}$ of sterilized soil. The soil was collected in the urban area of the Commune of Marrakesh $\left(31^{\circ} 39^{\prime} 07.3^{\prime \prime} \mathrm{N}\right.$, $8^{\circ} 04^{\prime} 04.3^{\prime \prime} \mathrm{W}$ ). The soil was passed through a $4 \mathrm{~mm}$ sieve and autoclaved (at $180^{\circ} \mathrm{C}$ for $3 \mathrm{~h}$ and repeated 3 times consecutively). The characteristics of the agricultural soil used in this study are mentioned in Table 1.

The experiment was set up in a randomized complete block design with two factors: biofertilizer application and salt stress levels $(0,120$ and $240 \mathrm{mM}$ of $\mathrm{NaCl})$. During transplantation, the biofertilizer treatments were established, consisting of different levels: Two AMF treatments-a 
PGPR treatment and a compost treatment established alone or in different combination, as described below. For the compost treatments, $2.375 \mathrm{~kg}$ of soil was mixed with $0.125 \mathrm{~kg}$ of compost at a rate of $5 \%$ and homogenized. The AMF treatments received either the native mycorrhizal consortium or the pure inoculum of $R$ irregularis. Inoculation was performed by adding $10 \mathrm{~g}$ of fresh inoculum containing root fragments and spores as closely as possible to the roots when transplanting. The non-mycorrhizal control received the same weight of previously autoclaved mycorrhizal inoculum. The PGPR treatments were inoculated twice, first during transplantation and 15 days later by spraying $15 \mathrm{~mL}(5 \times 109$ colony forming units $(\mathrm{CFU}) / \mathrm{mL}$ ) of the bacterial suspension as closely as possible to the roots using a micropipette.

The pots were grown for 4 months under controlled conditions (as described above) in the glasshouse at the Faculty of Science Semlalia, Cadi Ayyad University, Marrakesh, Morocco. Then, the vitroplants were subdivided into three groups: a control group without salt stress $(0 \mathrm{mM} \mathrm{NaCl})$, a second group supplemented with $120 \mathrm{mM}$ of $\mathrm{NaCl}$ and a third group with $240 \mathrm{mM}$ of $\mathrm{NaCl}$. Each group consisted of twelve biofertilizer treatments:

(1) Control plants without any biofertilizer (Control);

(2) Plants amended with compost (Comp);

(3) Plants inoculated with the native AMF consortium $\left(\mathrm{AMF}_{1}\right)$;

(4) Plants inoculated with the exotic AMF strain $\left(\mathrm{AMF}_{2}\right)$;

(5) Plants inoculated with the PGPR consortia (PGPR);

(6) $\mathrm{AMF}_{1}+$ Comp,

(7) $\mathrm{AMF}_{2}+$ Comp,

(8) PGPR+Comp,

(9) $\mathrm{PGPR}+\mathrm{AMF}_{1}$,

(10) $\mathrm{PGPR}+\mathrm{AMF}_{2}$,

(11) $\mathrm{PGPR}+\mathrm{AMF}_{1}+\mathrm{Comp}$,

(12) $\mathrm{PGPR}+\mathrm{AMF}_{2}+\mathrm{Comp}$.

In total 36 treatments were established with 8 replications for each treatment (one plant per pot is considered as a replicate), yielding a total of 288 pots.

\subsection{Data Collection and Analyses}

\subsubsection{Mycorrhizal Analysis}

After six months of planting, mycorrhizal frequency (F) and mycorrhizal intensity (I) of date palm roots were determined by the technique described by Trouvelot et al. [36]. Root tissues were cleared in $10 \% \mathrm{KOH}$ and stained with $0.05 \%$ trypan blue in lactic acid $(v / v)$ using the method of Phillips and Hayman [37]. The mycorrhizal frequency and the mycorrhizal intensity were calculated according to the following formula:

$$
\begin{aligned}
& \text { Mycorrhizal frequency (F) }(\%)=\left(\frac{\text { Infected root segments }}{\text { Total roots segments }}\right) \times 100 \\
& \text { Mycorrhizal intensity }(\mathrm{I})(\%)=\frac{(95 \mathrm{n} 5+70 \mathrm{n} 4+30 \mathrm{n} 3+5 \mathrm{n} 2+\mathrm{n} 1)}{\text { Total roots segments }}
\end{aligned}
$$

where " 5 " means the number of roots with infection level of 5 (infection rate 90-100\%), "n4" with infection level of 4 (infection rate 50-90\%), "n3" with level 3 (infection rate 10-50\%), "n2" with level 2 (infection rate 1-10\%) and "n1" with level 1 (infection rate $0-1 \%$ ). 


\subsubsection{Assessment of Date Palm Growth and Development}

After six months of planting, plants were harvested. Shoot and root elongation, the number of leaves and shoot and root fresh weights were measured to evaluate growth. The youngest peripheral roots were quickly frozen in liquid nitrogen and stored at $-20^{\circ} \mathrm{C}$ for further assays. The rest of the plant material was dried at $80^{\circ} \mathrm{C}$ until constant weight for dry weight and nutrient determination.

\subsubsection{Physiological Parameters}

Chlorophyll Fluorescence, Gas Exchange and Leaf Water Potential

Chlorophyll fluorescence (Fv/Fm) was measured with a fluorometer (OPTI-SCIENCE, OS30p). Eclipses were placed on top of the leaves for twenty minutes to keep the leaves in the dark. This parameter was measured on well-developed leaves of the same rank (four repetitions per treatment) and is expressed in Fv/Fm; Fv: variable fluorescence (Fm-F0) and Fm: maximum fluorescence, F0 being fluorescence in the initial state when all the reaction centers of the PSII are open (oxidized quinones).

Gas exchange (gs) was measured using a portable porometer (Leaf Porometer, Decagon Device, INC) on the fourth leaf from the apex as described by Harley et al. [38]. Eight repetitions per treatment were performed. The values of this parameter are expressed in mmoles $\mathrm{H}_{2} \mathrm{O} \mathrm{m}^{-2} \mathrm{~s}^{-1}$.

The leaf water potential (leaf $\Psi$ ) was measured between 06:00 AM and 08:00 AM with the method of the pressure chamber developed by Scholander et al. [39] using a pressure chamber instrument (PMS Instrument Company, Albany, OR, USA).

\section{Photosynthetic Pigment Quantification}

The concentrations of chlorophyll a and b respectively, total chlorophyll and carotenoids were determined according to the method described by Lichtenthaler [40]. Fresh leaf tissue (100 mg) was crushed in $80 \%$ acetone. After centrifugation at $10,000 \times g$ for $10 \mathrm{~min}$, the absorbance of the supernatants was recorded using a UV/visible spectrophotometer (UV-3100PC spectrophotometer) at 480, 645 and $663 \mathrm{~nm}$.

\subsubsection{Biochemical Traits}

\section{Total Soluble Sugars Quantification}

For sugar content determination, $0.1 \mathrm{~g}$ of leaves were homogenized with $8 \mathrm{~mL}$ of ethanol $(80 \%)$ and centrifuged at $5000 \mathrm{rpm}$ for $10 \mathrm{~min}$. To $200 \mu \mathrm{L}$ of supernatant, $200 \mu \mathrm{L}$ of phenol (5\%) and $1000 \mu \mathrm{L}$ of $\mathrm{H}_{2} \mathrm{SO}_{4}$ were added and agitated. After cooling, the absorbance at $485 \mathrm{~nm}$ was read [41].

Total Soluble Proteins and Antioxidant Enzyme Activities

Root samples $(0.1 \mathrm{~g})$ were homogenized in a cold mortar with $4 \mathrm{~mL}$ of $1 \mathrm{M}$ phosphate buffer $(\mathrm{pH} 7)$ containing $5 \%$ polyvinylpolypyrrolidone (PVPP). The homogenate was centrifuged at $18,000 \times g$ for $15 \mathrm{~min}$ at $4{ }^{\circ} \mathrm{C}$ and the supernatant was used for measuring antioxidant enzyme activities. Total soluble proteins were determined according to the method described by Bradford [42]. For catalase (CAT) assay, the reaction mixture consisted of $890 \mu \mathrm{L}$ of sodium phosphate buffer and $100 \mu \mathrm{L}$ of vegetal extract. The reaction started by the addition of $10 \mu \mathrm{L} 15 \% \mathrm{H}_{2} \mathrm{O}_{2}$. The activity was measured as the decrease in the absorbance at $240 \mathrm{~nm}$ [43]. Superoxide dismutase (SOD) activity was evaluated by monitoring the nitro-blue tetrazolium (NBT) reduction on formazan blue spectrophotometrically at $560 \mathrm{~nm}$ after $30 \mathrm{~min}$ under blue light [44]. The reaction mixture contained $2550 \mu \mathrm{L}$ sodium phosphate buffer $(0.1 \mathrm{mM}, \mathrm{pH} 6.0), 75 \mu \mathrm{L}$ of methionine $(55 \mathrm{mM}), 300 \mu \mathrm{L}$ of NBT $(0.75 \mathrm{mM})$ and $50 \mu \mathrm{L}$ of plant extract. The reaction was started with the addition of $60 \mu \mathrm{L}$ of riboflavin $(0.1 \mathrm{mM})$. Peroxidase (POD) activity was measured as described previously by Bergmeyer and Bernt [45]. The reaction mixture $\left(3000 \mu \mathrm{L}\right.$ ) contained $1 \mathrm{M}$ phosphate buffer (pH 7.0), $20 \mathrm{mM}$ guaiacol, $40 \mathrm{mM} \mathrm{H}_{2} \mathrm{O}_{2}$ and $100 \mu \mathrm{L}$ of the enzymatic extract, which was added to start the reaction. POD activity was determined at $470 \mathrm{~nm}$ by 
its ability to convert guaiacol to tetraguaiacol $\left(\varepsilon=26.6 \mathrm{mM}^{-1} \mathrm{~cm}^{-1}\right)$. The polyphenol oxidase (PPO) activity was determined by the method of Moore and Flurkey [46]. The assay solution contained $20 \mathrm{mM}$ catechol in $0.1 \mathrm{M}$ phosphate buffer ( $\mathrm{pH}$ 7). The reaction was started by the addition of $100 \mu \mathrm{L}$ of enzymatic extract. PPO activity was expressed in enzyme unit $\mathrm{mg}^{-1}$ protein. The activity was measured as the increase in the absorbance at $420 \mathrm{~nm}$. Control assays were done in the absence of the substrate in order to evaluate the auto-oxidation of the substrates. The antioxidant activities were expressed in $\mathrm{U} \mathrm{mg}$ protein ${ }^{-1} \mathrm{~min}^{-1}$.

\subsection{Soil Analyses}

At harvest, soil physicochemical properties were analyzed on samples taken near to the roots. The $\mathrm{pH}$ and electrical conductivity (EC) were measured in a diluted soil suspension $1 / 5(v / v)$ using a $\mathrm{pH}$ meter and a conductivity meter, respectively. Organic matter (OM) and total organic carbon (TOC) were measured according to the method described by Aubert [47] which consists of the oxidation of organic matter by potassium dichromate in the presence of sulfuric acid. Available phosphorus (AP) was determined according to Olsen and Sommers [48].

\subsection{Statistical Analysis}

Data were separately analyzed for each salt stress level using a one-way analysis of variance (ANOVA) followed by a comparison of the means with the Student-Newman-Keels test at the $5 \%$ threshold. Analyses were performed using the CoStat software version 6.400 (Copyright (C) 1998-2008 CoHort Software). The effects of PGPR inoculation, AMF inoculation, compost amendment, salinity and interaction among them on measured variables were tested by a two-way ANOVA using the Student-Newman-Keuls test at 0.05 threshold level.

\section{Results}

\subsection{Salt Stress and Compost Reduced AMF Root Colonization}

The mycorrhizal frequency $(\mathrm{F})$ of the vitroplant root system was negatively affected by salinity $(p<0.001, \mathrm{~F}=561.06)$. The application of native AMF consortium $\left(\mathrm{AMF}_{1}\right)$ and exotic AMF strain $\left(\mathrm{AMF}_{2}\right)$ allowed higher mycorrhizal frequencies, reaching $86 \%$ and $90 \%$ respectively, under non-stressed conditions (Figure 1). Under non-stressed conditions, the highest values were recorded in plants inoculated with PGPR+AMF2 reaching a frequency of $94 \%$, followed by the plants inoculated with PGPR+AMF1and $\mathrm{AMF}_{2}$ with frequencies of $92 \%$ and $90 \%$ respectively. Nevertheless, the application of compost with whatever AMF reduced mycorrhizal frequency. Under stressed conditions (120 and $240 \mathrm{mM}$ ), the same findings were observed. The combined application of PGPR and AMF resulted in the highest records reaching $82 \%$ by the PGPR+AMF2 treatment under $120 \mathrm{mM}$ conditions and $81 \%$ by the PGPR+AMF1 under $240 \mathrm{mM}$ conditions.

As for the mycorrhizal frequency, the mycorrhizal intensity was significantly affected by salinity $(p<0.001, \mathrm{~F}=760.41)$, especially under $240 \mathrm{mM}$ of $\mathrm{NaCl}$. However, the combined use of PGPR and $\mathrm{AMF}_{2}$ improved mycorrhizal intensity under both salinity levels. Under non-stressed conditions, the PGPR+AMF2 treatment resulted in the highest mycorrhizal intensity reaching $64 \%$, followed by PGPR+AMF1 (62\%), $\mathrm{AMF}_{2}(61 \%)$ and $\mathrm{AMF}_{1}(60 \%)$ treatments. Under stressed conditions, the PGPR+AMF2 treatment also gave the highest mycorrhizal intensity compared to the other treatments. Based on these results, we can point out the negative effect of salinity and compost on AMF colonization. 

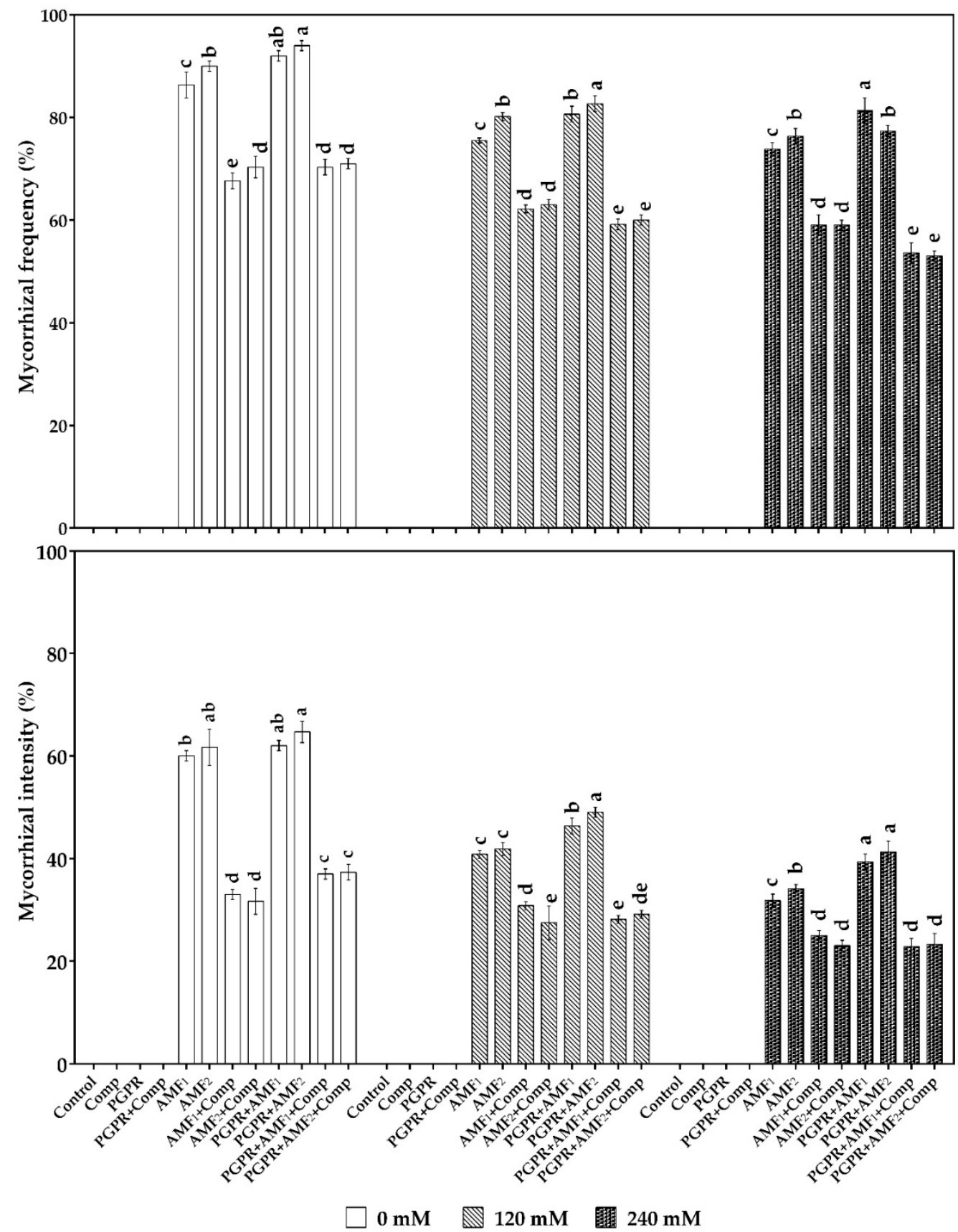

Figure 1. Effects of salt stress and biofertilizers on arbuscular mycorrhizal fungal (AMF) root colonization frequency and intensity of date palm vitroplants. Comp: compost; $\mathrm{AMF}_{1}$ : native $\mathrm{AMF}$ consortium; $\mathrm{AMF}_{2}$ : AMF pure strain; PGPR plant growth promoting rhizobacteria. Data presented are means \pm standard deviations, $\mathrm{n}=3$. Bars followed by the same letters within the same salt stress level are not significantly different according to Student-Newman-Keuls test $(p<0.05)$.

\subsection{Biofertilizers Improved Date Palm Growth Parameters under Salt Stress}

Biofertilizers significantly affected the height $(p<0.001, \mathrm{~F}=35.08)$ of vitroplants under all salinity levels. The two tripartite combinations PGPR+AMF1+Comp and PGPR+AMF2+Comp in particular efficiently increased plant height compared to the controls, with respective enhancements of $47 \%$ and $48 \%$ under non-stressed conditions $(0 \mathrm{mM}), 44 \%$ and $43 \%$ under $120 \mathrm{mM} \mathrm{NaCl}$ and $42 \%$ and $41 \%$ under $240 \mathrm{mM} \mathrm{NaCl}$ (Table 2). 
Table 2. Effects of biofertilizers on growth parameters of date palm vitroplants under different salt $(\mathrm{NaCl})$ stress levels, 0,120 and $240 \mathrm{mM}$.

\begin{tabular}{|c|c|c|c|}
\hline $\mathrm{NaCl}$ & Treatment & Leaf Number & Plant Height (cm) \\
\hline \multirow{12}{*}{$0 \mathrm{mM}$} & Control & $5.33(1.53)^{\mathrm{a}}$ & $33.50(3.28)^{b}$ \\
\hline & Comp & $6.67(1.15)^{\mathrm{a}}$ & $42.00(9.16)^{a}$ \\
\hline & $\mathrm{AMF}_{1}$ & $7.67(0.58)^{\mathrm{a}}$ & $41.67(3.51)^{\mathrm{a}}$ \\
\hline & $\mathrm{AMF}_{2}$ & $5.33(1.53)^{\mathrm{a}}$ & $42.63(1.18)^{a}$ \\
\hline & PGPR & $5.67(1.15)^{\mathrm{a}}$ & $46.07(1.01)^{\mathrm{a}}$ \\
\hline & $\mathrm{AMF}_{1}+$ Comp & $7.33(1.15)^{\mathrm{a}}$ & $47.27(0.64)^{a}$ \\
\hline & $\mathrm{AMF}_{2}+$ Comp & $7.00(1.00)^{\mathrm{a}}$ & $45.67(1.53)^{a}$ \\
\hline & PGPR+Comp & $6.67(0.58)^{\mathrm{a}}$ & $44.17(0.76)^{a}$ \\
\hline & $\mathrm{PGPR}+\mathrm{AMF}_{1}$ & $6.33(0.58)^{a}$ & $45.93(0.90)^{a}$ \\
\hline & $\mathrm{PGPR}+\mathrm{AMF}_{2}$ & $6.00(1.00)^{\mathrm{a}}$ & $46.97(0.35)^{\mathrm{a}}$ \\
\hline & $\mathrm{PGPR}+\mathrm{AMF}_{1}+$ Comp & $7.67(0.58)^{\mathrm{a}}$ & $47.87(0.81)^{a}$ \\
\hline & $\mathrm{PGPR}+\mathrm{AMF}_{2}+$ Comp & $6.67(1.53)^{\mathrm{a}}$ & $48.10(0.96)^{\mathrm{a}}$ \\
\hline \multirow{12}{*}{$120 \mathrm{mM}$} & Control & $4.00(1.00)^{\mathrm{a}}$ & $29.00(1.00)^{d}$ \\
\hline & Comp & $4.33(1.53)^{\mathrm{a}}$ & $31.33(2.08)^{c, d}$ \\
\hline & $\mathrm{AMF}_{1}$ & $6.33(0.58)^{\mathrm{a}}$ & $31.03(1.55)^{c, d}$ \\
\hline & $\mathrm{AMF}_{2}$ & $4.67(0.58)^{\mathrm{a}}$ & $32.50(1.32)^{c}$ \\
\hline & PGPR & $5.33(0.58)^{\mathrm{a}}$ & $30.23(1.12){ }^{c, d}$ \\
\hline & $\mathrm{AMF}_{1}+$ Comp & $6.00(1.00)^{\mathrm{a}}$ & $43.5(0.50)^{a}$ \\
\hline & $\mathrm{AMF}_{2}+$ Comp & $5.67(0.58)^{\mathrm{a}}$ & $43.17(0.76)^{\mathrm{a}}$ \\
\hline & PGPR+Comp & $5.00(1.00)^{\mathrm{a}}$ & $40.50(0.50)^{b}$ \\
\hline & $\mathrm{PGPR}+\mathrm{AMF}_{1}$ & $6.00(1.00)^{\mathrm{a}}$ & $40.20(1.25)^{b}$ \\
\hline & $\mathrm{PGPR}+\mathrm{AMF}_{2}$ & $5.67(0.58)^{\mathrm{a}}$ & $43.50(2.18)^{a}$ \\
\hline & $\mathrm{PGPR}+\mathrm{AMF}_{1}+$ Comp & $6.33(1.00)^{\mathrm{a}}$ & $44.50(0.50)^{\mathrm{a}}$ \\
\hline & $\mathrm{PGPR}+\mathrm{AMF}_{2}+$ Comp & $5.33(0.58)^{\mathrm{a}}$ & $43.83(0.76)^{a}$ \\
\hline \multirow{12}{*}{$240 \mathrm{mM}$} & Control & $3.33(0.58)^{b}$ & $23.33(0.76)^{e}$ \\
\hline & Comp & $3.33(0.58)^{b}$ & $29.33(1.53)^{c}$ \\
\hline & $\mathrm{AMF}_{1}$ & $4.67(0.58)^{a, b}$ & $28.17(0.76)^{c}$ \\
\hline & $\mathrm{AMF}_{2}$ & $3.33(0.58)^{b}$ & $27.47(0.61)^{\mathrm{c}, \mathrm{d}}$ \\
\hline & PGPR & $4.67(0.58)^{a, b}$ & $25.37(2.95) \mathrm{d}, \mathrm{e}$ \\
\hline & $\mathrm{AMF}_{1}+$ Comp & $5.67(1.15)^{a, b}$ & $34.23(0.75)^{b}$ \\
\hline & $\mathrm{AMF}_{2}+$ Comp & $5.33(0.58)^{a, b}$ & $34.60(0.79)^{b}$ \\
\hline & PGPR+Comp & $4.33(0.58)^{a, b}$ & $36.63(0.71)^{b}$ \\
\hline & $\mathrm{PGPR}+\mathrm{AMF}_{1}$ & $4.67(0.58)^{a, b}$ & $36.77(1.75)^{b}$ \\
\hline & $\mathrm{PGPR}+\mathrm{AMF}_{2}$ & $4.67(0.58)^{a, b}$ & $36.37(1.10)^{b}$ \\
\hline & $\mathrm{PGPR}+\mathrm{AMF}_{1}+$ Comp & $6.00(1.00)^{\mathrm{a}}$ & $42.07(0.90)^{\mathrm{a}}$ \\
\hline & $\mathrm{PGPR}+\mathrm{AMF}_{2}+\mathrm{Comp}$ & $4.67(0.58)^{a, b}$ & $41.36(0.78)^{\mathrm{a}}$ \\
\hline
\end{tabular}

Comp: compost; $\mathrm{AMF}_{1}$ : $\mathrm{AMF}$ consortium; $\mathrm{AMF}_{2}$ : AMF pure strain; PGPR: plant growth promoting rhizobacteria. Data presented are means (standard deviation), $\mathrm{n}=3$. Different lowercase letters within a column indicate significant differences between the means of the same parameter analyzed at $p<0.05$

The accumulation of biomass (shoot dry weight and root dry weight) are critical growth parameters since the impact of salt stress on plant growth and development is a consequence of the effects of this constraint on physiological, biochemical and nutritional aspects. In this study, shoot dry weight (SDW) was significantly affected by biofertilizers under all salinity levels $(p<0.001, \mathrm{~F}=41.58)$. Under non-stressed conditions, all biofertilizers alone or in combination significantly increased SDW compared to control plants (Figure 2), except the bipartite combination PGPR+Comp. At $120 \mathrm{mM}$ $\mathrm{NaCl}$ level, all treatments except the Comp, $\mathrm{AMF}_{1}, \mathrm{PGPR}$ and PGPR+Comp treatments increased SDW compared to control plants. The bipartite combination $\mathrm{AMF}_{1}+\mathrm{Comp}$ resulted in the highest enhancement of $189 \%$ compared to the control. Under $240 \mathrm{mM} \mathrm{NaCl}$ level, the PGPR, $\mathrm{AMF}_{1}+\mathrm{Comp}$ and PGPR+AMF1+Comptreatments were the most effective in increasing the SDW by 128\%, 122\% and $113 \%$ respectively compared to the $240 \mathrm{mM} \mathrm{NaCl}$-stressed control plants. 
Accordingly, the root dry weight (RDW) was also significantly increased by biofertilizer treatment under all salt stress levels $(p<0.001, \mathrm{~F}=114.25)$. Under non-stressed conditions, the tripartite combination PGPR $+\mathrm{AMF}_{2}+\mathrm{Comp}$ presented the highest improvement of $187 \%$ over the control. At $120 \mathrm{mM}$, the highest record was obtained by the application of the bipartite combination $\mathrm{AMF}_{2}+\mathrm{Comp}$, which increased RDW by $161 \%$ compared to the control. In addition, under the highest salt stress, only the bipartite $\mathrm{AMF}_{2}+\mathrm{Comp}(155 \%)$ and tripartite $\mathrm{PGPR}+\mathrm{AMF}_{1}+\mathrm{Comp}(139 \%)$ treatments significantly increased the RDW compared to the salt-stressed control.

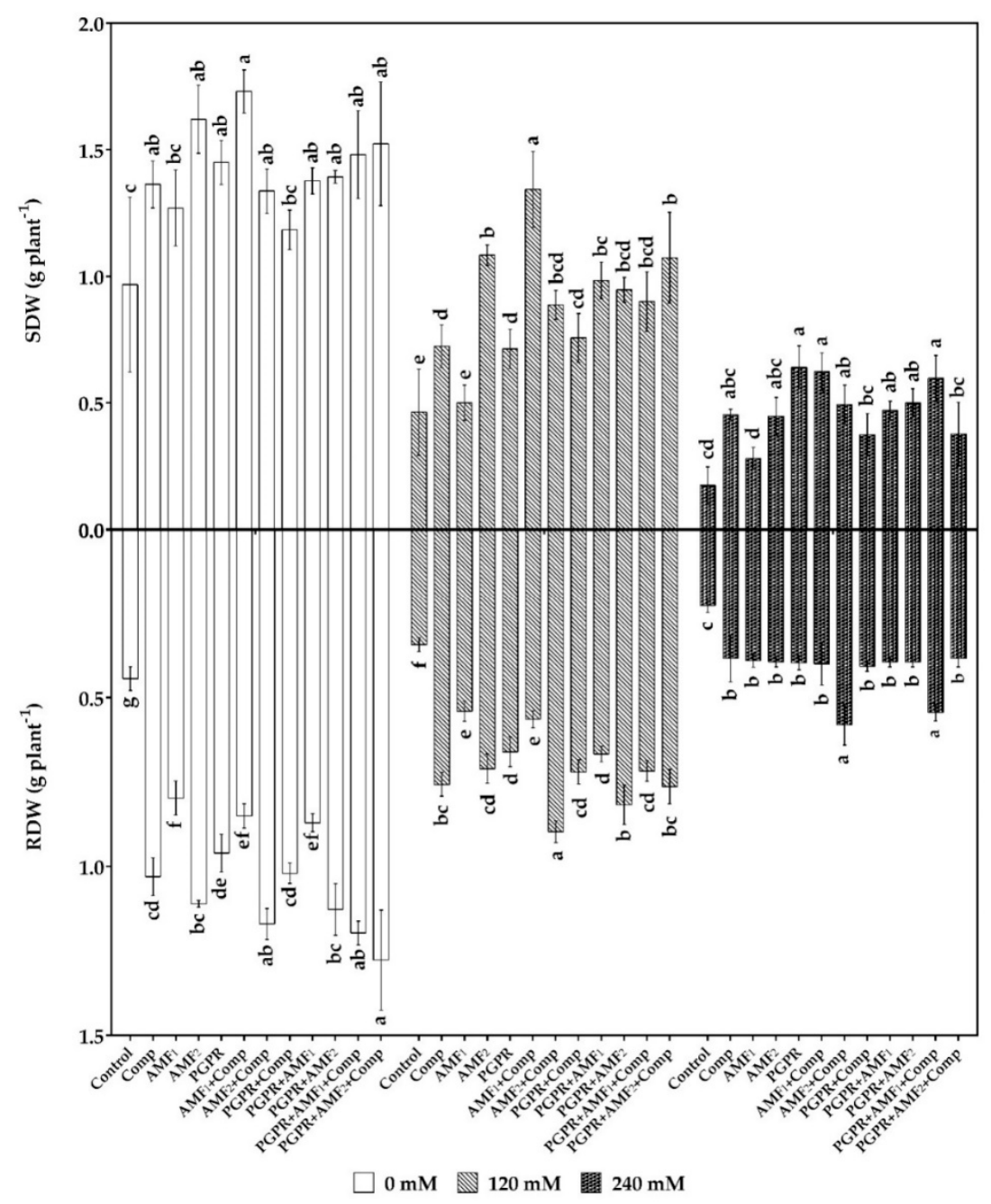

Figure 2. Effects of salt stress and biofertilizers on shoot dry weight (SDW) and root dry weight (RDW) of date palm vitroplants. Comp: compost; $\mathrm{AMF}_{1}$ : $\mathrm{AMF}$ consortium; $\mathrm{AMF}_{2}$ : $\mathrm{AMF}$ pure strain; PGPR plant growth promoting rhizobacteria. Data presented are means \pm standard deviations, $\mathrm{n}=3$. Bars followed by the same letters within the same salt stress level are not significantly different according to Student-Newman-Keuls test $(p<0.05)$.

\subsection{Biofertilizers Promoted Date Palm Chlorophyll Fluorescence, Gas Exchange and Leaf Water Potential under} Salt Stress

Chlorophyll fluorescence was not affected by biofertilizer application (data not presented). In contrast, gas exchange (gs) and leaf water potential (leaf $\Psi$ ) were both affected by biofertilizer application under all salinity levels (Table 3). Figure 3 showed that the application of biofertilizers improved the gs $(p<0.001, \mathrm{~F}=11.22)$, except for the stressed plants treated by Comp, $\mathrm{AMF}_{1}, \mathrm{AMF}_{2}$, PGPR and $\mathrm{AMF}_{1}+\mathrm{Comp}$, which presented no significant difference compared to stress controls. A high enhancement of $50 \%$ was recorded by the tripartite combination PGPR+AMF2+Comp. Under both 
stress levels, almost all bi- and tripartite biofertilizer combinations increased gs compared to the respective controls. Accordingly, the application of biofertilizers alone or in combination significantly lowered the negative effect of salt stress by increasing leaf water potential compared to the controls $(p<0.001, \mathrm{~F}=639.24)$. The two tripartite combinations PGPR+AMF1+Comp and PGPR+AMF2+Comp significantly enhanced the leaf $\Psi$ by $52 \%$ and $58 \%$, respectively, under non-stressed conditions, and $28 \%$ and $27 \%$, respectively, under $120 \mathrm{mM} \mathrm{NaCl}$ level compared to the controls. However, under $240 \mathrm{mM}$ level, the highest enhancement of $24 \%$ was recorded by the bipartite combination PGPR+Comp.
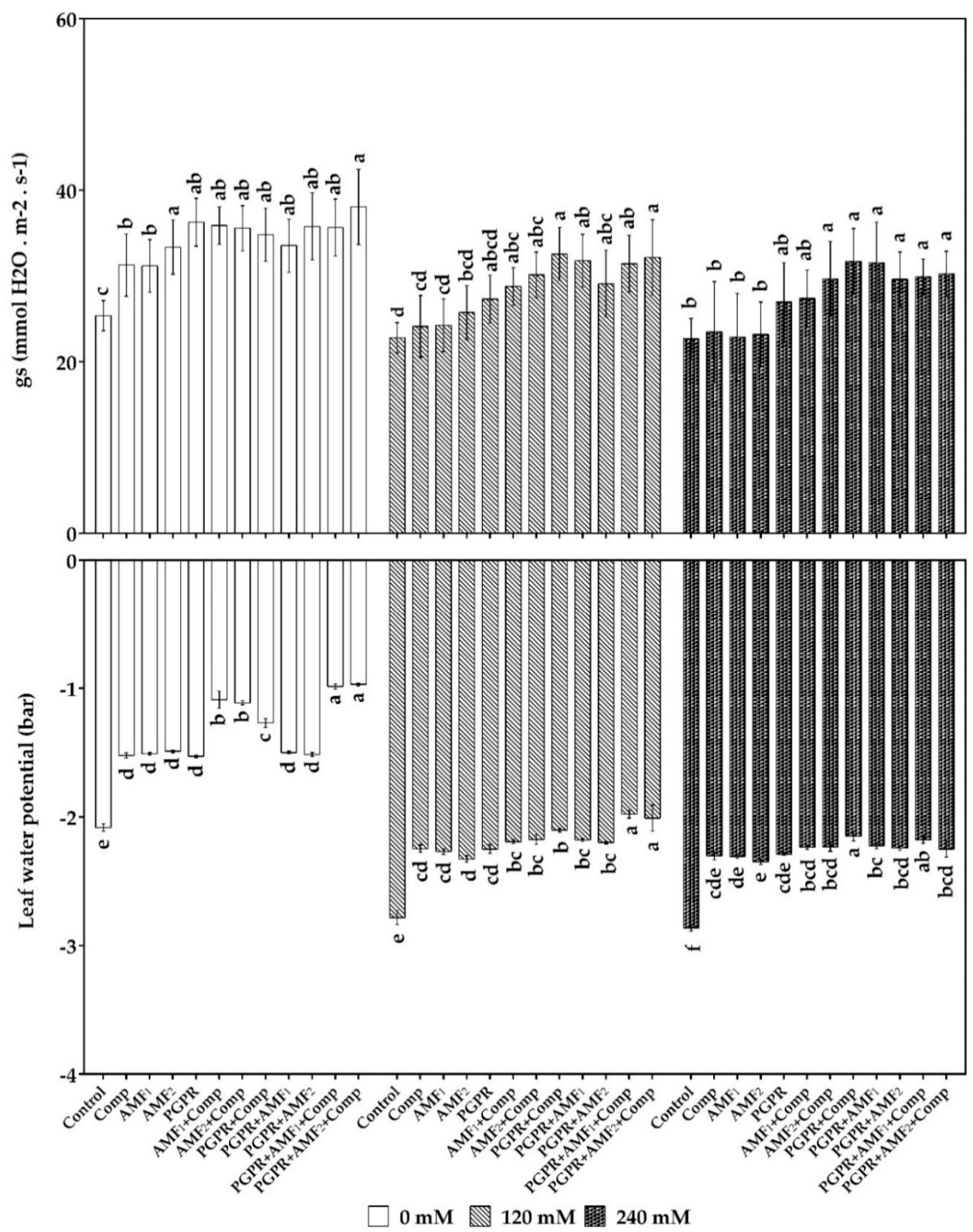

Figure 3. Effects of salt stress and biofertilizers on gas exchange (gs) and leaf water potential of date palm vitroplants. Comp: compost; AMF1: AMF consortium; AMF2: AMF pure strain; PGPR: plant growth promoting rhizobacteria. Data presented are means \pm standard deviations, $(g s: n=8 ; \Psi: n=$ 3). Bars followed by the same letters within the same salt stress level are not significantly different according to Student-Newman-Keuls test $(p<0.05)$. 
Table 3. Results of a four-way ANOVA test for independent variables, including salinity, PGPR inoculation, AMF inoculation and compost amendment, and interactions among them.

\begin{tabular}{|c|c|c|c|c|c|c|c|c|c|c|c|c|c|c|c|}
\hline & AMF & PGPR & $\begin{array}{c}\text { AMF } \\
x \\
\text { PGPR }\end{array}$ & Compost & $\begin{array}{c}\text { AMF } \\
x \\
\text { Compost }\end{array}$ & $\begin{array}{c}\text { PGPR } \\
x \\
\text { Compost }\end{array}$ & $\begin{array}{c}\text { AMF } \\
x \\
\text { PGPR } \\
x \\
\text { Compost }\end{array}$ & Salinity & $\begin{array}{c}\text { AMF } \\
\text { x } \\
\text { Salinity }\end{array}$ & $\begin{array}{c}\text { PGPR } \\
x \\
\text { Salinity }\end{array}$ & $\begin{array}{c}\text { AMF } \\
x \\
\text { PGPR } \\
x \\
\text { Salinity }\end{array}$ & $\begin{array}{c}\text { Compost } \\
x \\
\text { Salinity }\end{array}$ & $\begin{array}{c}\text { AMF } \\
x \\
\text { Compost } \\
x \\
\text { Salinity }\end{array}$ & $\begin{array}{c}\text { PGPR } \\
x \\
\text { Compost } \\
x \\
\text { Salinity }\end{array}$ & $\begin{array}{c}\text { AMF } \\
x \\
\text { PGPR } \\
x \\
\text { Compost } \\
x \\
\text { Salinity }\end{array}$ \\
\hline Plant height & $* * *$ & $* * *$ & ns & $* * *$ & ns & $* *$ & $* *$ & $* * *$ & * & * & ${ }^{* *}$ & $* * *$ & ns & $* *$ & $* * *$ \\
\hline Leaves number & $* * *$ & ns & ns & $* *$ & ns & ns & $*$ & $* * *$ & ns & ns & ns & ns & ns & ns & ns \\
\hline SDW & $* * *$ & * & * & $* * *$ & $* * *$ & $* * *$ & $* * *$ & $* * *$ & $* * *$ & ns & ns & ns & ns & ns & $* * *$ \\
\hline RDW & $* * *$ & $* * *$ & $* * *$ & $* * *$ & $* * *$ & $* * *$ & $* * *$ & $* * *$ & $* * *$ & $* * *$ & ns & $* * *$ & $* * *$ & $* *$ & $* * *$ \\
\hline $\mathrm{F} \%$ & $* * *$ & $* *$ & $* * *$ & $* * *$ & $* * *$ & $* * *$ & $* * *$ & $* * *$ & $* * *$ & $* * *$ & $* *$ & $*$ & ns & $* * *$ & * \\
\hline $\mathrm{I} \%$ & $* * *$ & $* * *$ & $* * *$ & $* * *$ & $* * *$ & $* * *$ & $* * *$ & $* * *$ & $* * *$ & ns & ns & $* * *$ & $* * *$ & $* * *$ & $* *$ \\
\hline gs & $* * *$ & $* * *$ & $* *$ & $* * *$ & ns & $*$ & ns & $* * *$ & ns & ns & ns & $\mathrm{ns}$ & ns & ns & $* *$ \\
\hline Leaf water potential & $* * *$ & $* * *$ & $* * *$ & $* * *$ & $* * *$ & $* * *$ & $* * *$ & $* * *$ & $* * *$ & $* *$ & $* * *$ & $* * *$ & $* * *$ & $* * *$ & $*$ \\
\hline $\mathrm{Chl} \mathrm{a}$ & $* * *$ & $* * *$ & ns & $* * *$ & ns & $*$ & ns & $* * *$ & ns & $* * *$ & ns & $*$ & ns & ns & ns \\
\hline $\mathrm{Chl} \mathrm{b}$ & $* * *$ & $* * *$ & $* * *$ & $* * *$ & ns & $*$ & ns & $* * *$ & ns & ${ }^{*}$ & $*$ & ns & ns & $*$ & ns \\
\hline Total chlorophyll & $* * *$ & $* * *$ & ns & $* * *$ & ns & ns & ns & $* * *$ & ns & $* * *$ & ns & $*$ & ns & ns & ns \\
\hline Carotenoids & $* *$ & $* * *$ & ns & $* * *$ & ns & ns & ns & $* * *$ & ns & $* * *$ & ns & ns & ns & ns & ns \\
\hline $\mathrm{PPO}$ & $* * *$ & $* * *$ & $* *$ & ns & $* * *$ & $* * *$ & $* * *$ & $* * *$ & $* * *$ & $* * *$ & $* * *$ & $* * *$ & $* * *$ & $* * *$ & $* * *$ \\
\hline POD & $* * *$ & $* * *$ & $* * *$ & $* * *$ & $* * *$ & $* * *$ & $* * *$ & $* * *$ & $* * *$ & $* * *$ & $* *$ & ns & $* * *$ & $*$ & ns \\
\hline CAT & $* * *$ & $* * *$ & $* * *$ & $* * *$ & $* * *$ & $* * *$ & ns & $* * *$ & $* * *$ & $* * *$ & ns & $* * *$ & $* * *$ & $* * *$ & $* *$ \\
\hline SOD & $* * *$ & $* * *$ & $* * *$ & $* * *$ & $* * *$ & $* * *$ & $* * *$ & $* * *$ & $* * *$ & $* * *$ & $* * *$ & $* * *$ & ns & $* * *$ & $* * *$ \\
\hline Sugar content & $* * *$ & $* * *$ & $* * *$ & $* * *$ & $* * *$ & $* * *$ & $* * *$ & $* * *$ & ns & $* * *$ & ns & $* * *$ & $*$ & $* *$ & $* * *$ \\
\hline Proteins content & $* * *$ & $* * *$ & $* * *$ & $* * *$ & ns & $*$ & ns & $* * *$ & $* * *$ & $* * *$ & ns & ns & ns & ns & ns \\
\hline $\mathrm{pH}$ & $* * *$ & $* * *$ & $* * *$ & $* * *$ & $*$ & $* * *$ & ns & $* * *$ & $* * * *$ & $* * *$ & $* * *$ & $* * *$ & ns & ns & $* * *$ \\
\hline EC & ns & $* * *$ & $* * *$ & $* * *$ & $* * *$ & $* * *$ & $* * *$ & $* * *$ & $* * *$ & $* * *$ & $* * *$ & $* * *$ & $* * *$ & $* * *$ & $* * *$ \\
\hline TOC $\%$ & $* * *$ & $* * *$ & $* * *$ & $* * *$ & ns & ns & $* * *$ & $* * *$ & $*$ & $* * *$ & $* * *$ & * & $* * *$ & $* * *$ & ns \\
\hline $\mathrm{OM} \%$ & $* * *$ & $* * *$ & $* * *$ & $* * *$ & $\mathrm{~ns}$ & ns & $* * *$ & $* * *$ & $*$ & $* * *$ & $* * *$ & $*$ & $* * *$ & $* * *$ & ns \\
\hline $\mathrm{P}$ & $* * *$ & $* * *$ & $* * *$ & $* * *$ & $* * *$ & $* * *$ & $* * *$ & $* * *$ & $* * *$ & $* * *$ & $* * *$ & $* * *$ & $* * *$ & $* * *$ & $* * *$ \\
\hline
\end{tabular}

ns: not significant; ${ }^{*}$ significant at $p<0.05 ;{ }^{* *}$ significant at $p<0.005 ;$;** significant at $p<0.001$. SDW: shoot dry weight; RDW: root dry weight; gs: gas exchange; F\%: mycorrhizal frequency; I\%: mycorrhizal intensity; Chla: chlorophyll a; Chlb: chlorophyll b; PPO: polyphenoloxidase; POD: peroxidase; CAT: catalase; SOD: superoxide dismutase; EC: electrical conductivity; TOC: total organic carbon; OM: organic matter; P: soil $\mathrm{P}_{\text {olsen }}$. 


\subsection{Biofertilizers Stimulated Date Palm Chlorophyll and Carotenoid Production under Salt Stress}

The finding reported in Table 4 showed that under salt stress, the photosynthetic pigment contents were significantly reduced $(p<0.001$; Table 3$)$. However, the applications of AMF, compost, and PGPR, especially their combination, increased photosynthetic pigment contents compared to the stressed control plants. Under non-stressed conditions, chlorophyll a (Chl a) content was increased by the different treatments, except for Comp, $\mathrm{AMF}_{1}$ and $\mathrm{AMF}_{2}$ treatments, which had no significant effects compared to the control plants (Table 4). Under the $120 \mathrm{mM}$ level, $\mathrm{AMF}_{2}+\mathrm{Comp}, \mathrm{PGPR}+\mathrm{Comp}$, $\mathrm{PGPR}+\mathrm{AMF}_{1}, \mathrm{PGPR}+\mathrm{AMF}_{2}, \mathrm{PGPR}+\mathrm{AMF}_{1}+\mathrm{Comp}$ and $\mathrm{PGPR}+\mathrm{AMF}_{2}+$ Comp significantly increased the $\mathrm{Chl}$ a content compared to control plants. However, under the $240 \mathrm{mM}$ level, no significant difference was recorded between the applied treatments and the control plants. As for Chlorophyll $\mathrm{b}\left(\mathrm{Chl}\right.$ b) content, it was increased by $\mathrm{AMF}_{2}, \mathrm{PGPR}, \mathrm{PGPR}+\mathrm{Comp}, \mathrm{PGPR}+\mathrm{AMF}_{1}, \mathrm{PGPR}+\mathrm{AMF}_{2}$, $\mathrm{PGPR}+\mathrm{AMF}_{1}+\mathrm{Comp}$ and $\mathrm{PGPR}+\mathrm{AMF}_{2}+\mathrm{Comp}$ treatments under non-stressed conditions (Table 4). The two tripartite combinations $\mathrm{PGPR}+\mathrm{AMF}_{1}+\mathrm{Comp}$ and $\mathrm{PGPR}+\mathrm{AMF}_{2}+\mathrm{Comp}$ were the most effective at improving $\mathrm{Chl} b$ by $158 \%$ and $157 \%$, respectively, compared to the control. For the $120 \mathrm{mM}$ level, $\mathrm{PGPR}+\mathrm{AMF}_{1}, \mathrm{PGPR}+\mathrm{AMF}_{2}, \mathrm{PGPR}+\mathrm{AMF}_{1}+\mathrm{Comp}$ and $\mathrm{PGPR}+\mathrm{AMF}_{2}+\mathrm{Comp}$ treatments significantly increased the $\mathrm{Chl} b$ amount by $73 \%, 83 \%, 131 \%$ and $141 \%$ respectively, compared to control plants. Under $240 \mathrm{mM}$ level, $\mathrm{PGPR}, \mathrm{AMF}_{2}+\mathrm{Comp}, \mathrm{PGPR}+\mathrm{Comp}, \mathrm{PGPR}+\mathrm{AMF}_{1}, \mathrm{PGPR}+\mathrm{AMF}_{2}$, $\mathrm{PGPR}+\mathrm{AMF}_{1}+\mathrm{Comp}$ and $\mathrm{PGPR}+\mathrm{AMF}_{2}+\mathrm{Comp}$ treatments increased the concentration of $\mathrm{Chl} \mathrm{b}$ compared to the control. According to the total chlorophyll content, the $\mathrm{AMF}_{2}+\mathrm{Comp}, \mathrm{PGPR}+\mathrm{Comp}$, $\mathrm{PGPR}+\mathrm{AMF}_{1}, \mathrm{PGPR}+\mathrm{AMF}_{2}, \mathrm{PGPR}+\mathrm{AMF}_{1}+\mathrm{Comp}$ and $\mathrm{PGPR}+\mathrm{AMF}_{2}+\mathrm{Comp}$ treatments significantly increased this parameter independently of salinity level (Table 4). However, PGPR and $\mathrm{AMF}_{1}+\mathrm{Comp}$ treatment increased total chlorophyll content under non-stressed conditions and $240 \mathrm{mM}$ salinity level. The PGPR $+\mathrm{AMF}_{1}+\mathrm{Comp}$ and $\mathrm{PGPR}+\mathrm{AMF}_{2}+\mathrm{Comp}$ treatments recorded the highest increments $(75 \%$ and $77 \%$ respectively) under non-stressed conditions compared to the control plants. Concerning the carotenoid content, under non-stressed conditions, all treatments enhanced this parameter except for Comp, $\mathrm{AMF}_{1}$ and $\mathrm{AMF}_{2}$ treatments, which showed no significant effect on carotenoid content compared to the control plants (Table 4). However, under stressed conditions, bipartite and tripartite combinations $\left(\mathrm{PGPR}+\mathrm{AMF}_{1}, \mathrm{PGPR}+\mathrm{AMF}_{2}, \mathrm{PGPR}+\mathrm{AMF}_{1}+\mathrm{Comp}\right.$ and $\left.\mathrm{PGPR}+\mathrm{AMF}_{2}+\mathrm{Comp}\right)$ significantly increased the carotenoid content compared to control plants under $120 \mathrm{mM}$ salinity level.

\subsection{Biofertilizers Increased Date Palm Biochemical Parameters under Salt Stress}

The sugar content was significantly affected by salt stress $(p<0.001, \mathrm{~F}=942.42 ;$ Table 3$)$. However, the application of the biofertilizers enhanced the accumulation of sugar in plants compared to the control plants (Table 4). We noted clearly that PGPR bacteria, AMF and compost alone or in the different combinations significantly increased the amount of sugar compared to non-inoculated and non-amended control plants. The highest sugar concentrations were recorded in plants treated with the two tripartite combinations ( $\mathrm{PGPR}+\mathrm{AMF}_{1}+\mathrm{Comp}$ and $\mathrm{PGPR}+\mathrm{AMF}_{2}+\mathrm{Comp}$ ) - enhancements of $73 \%$ and $71 \%(0 \mathrm{mM}), 58 \%$ and $54 \%(120 \mathrm{mM})$ and $86 \%$ and $83 \%(240 \mathrm{mM})$, respectively compared to the controls. According to the protein content, it was slightly affected by salt stress. Only the high level of salt stress affected the protein concentration. The applied biofertilizers significantly enhanced the amount of proteins compared to the control plants at whatever salinity level, except the comp treatment, which had no significant effect. 
Table 4. Effects of biofertilizers on sugar, protein and photosynthetic pigment contents of date palm vitroplants.

\begin{tabular}{|c|c|c|c|c|c|c|c|}
\hline $\mathrm{NaCl}$ & Treatments & $\begin{array}{l}\text { Chl a Content } \\
\left(\mathrm{mg} \mathrm{g}^{-1} \text { FW) }\right.\end{array}$ & $\begin{array}{l}\text { Chl b Content } \\
\left(\mathrm{mg} \mathrm{g}^{-1} \text { FW) }\right.\end{array}$ & Total Chlorophyll Content (mg g ${ }^{-1}$ FW) & $\begin{array}{l}\text { Carotenoids Content } \\
\quad\left(\mathrm{mg} \mathrm{g}^{-1} \mathrm{FW}\right)\end{array}$ & $\begin{array}{c}\text { Sugar Content } \\
\left.\text { (mg eq. Glucose } \mathrm{g}^{-1} \mathrm{FW}\right)\end{array}$ & $\begin{array}{c}\text { Protein Content } \\
\text { (mg eq. SAB g }{ }^{-1} \text { FW }\end{array}$ \\
\hline \multirow{12}{*}{$0 \mathrm{mM}$} & Control & $13.94(0.97)^{\mathrm{c}}$ & $4.17(0.22)^{\mathrm{c}}$ & $18.12(1.16)^{d}$ & $72.33(4.57) \mathrm{b}, \mathrm{c}$ & $53.00(1.00)^{\mathrm{d}}$ & $3.17(0.76)^{\mathrm{e}}$ \\
\hline & Comp & $15.13(3.96)^{b, c}$ & $5.90(2.13) \mathrm{b}, \mathrm{c}$ & $21.03(6.07)^{c, d}$ & 75.78 (16.10) a,b,c & $73.67(1.58)^{\mathrm{c}}$ & $3.43(0.40)^{\mathrm{e}}$ \\
\hline & $\mathrm{AMF}_{1}$ & $14.76(2.06)^{\mathrm{b}, \mathrm{c}}$ & $5.94(0.92) \mathrm{b}, \mathrm{c}$ & $20.70(2.04)^{c, d}$ & $68.83(3.88)^{c}$ & $72.00(1.00)^{\mathrm{c}}$ & $5.50(0.87)^{c, d}$ \\
\hline & $\mathrm{AMF}_{2}$ & $14.38(1.17)^{\mathrm{b}, \mathrm{c}}$ & $6.58(1.49)^{b, c}$ & $20.96(0.82)^{c, d}$ & $69.97(3.05)^{\mathrm{c}}$ & $73.00(1.00)^{\mathrm{c}}$ & $5.60(0.36)^{c, d}$ \\
\hline & PGPR & $19.17(2.39)^{a, b}$ & $6.84(0.31)^{b, c}$ & $26.02(2.23)^{a}, b, c$ & $92.45(7.58)^{a}, b, c$ & $71.67(7.23)^{\mathrm{c}}$ & $5.33(1.04)^{\mathrm{d}}$ \\
\hline & $\mathrm{AMF}_{1}+\mathrm{Comp}$ & $19.28(2.89)^{\mathrm{ab}}$ & $6.06(1.15)^{b, c}$ & $25.34(4.05)^{b, c}$ & $88.75(7.76)^{a, b, c}$ & $86.00(1.00)^{a, b}$ & $6.27(0.87)^{\mathrm{b}, \mathrm{c}, \mathrm{d}}$ \\
\hline & $\mathrm{AMF}_{2}+\mathrm{Comp}$ & $19.56(2.63)^{\mathrm{ab}}$ & $6.30(1.32) \mathrm{b}, \mathrm{c}$ & $25.86(3.32) \mathrm{a}, \mathrm{b}, \mathrm{c}$ & $93.19(11.15)^{a, b, c}$ & $86.33(2.08)^{a, b}$ & $6.37(1.00)^{b, c, d}$ \\
\hline & PGPR+Comp & $19.93(2.04)$ ab & $7.87(1.30)^{\mathrm{b}}$ & $27.81(3.26)^{a b}$ & $94.68(11.54)^{a, b, c}$ & $86.67(2.08)^{a, b}$ & $7.20(0.53)^{a, b}$ \\
\hline & $\mathrm{PGPR}+\mathrm{AMF}_{1}$ & $19.93(2.29)^{\mathrm{ab}}$ & $8.62(1.80)^{a, b}$ & $28.56(2.05)^{a, b}$ & $96.79(13.31)^{a, b, c}$ & $85.33(1.53)^{\mathrm{b}}$ & $7.03(0.15)^{a, b, c}$ \\
\hline & $\mathrm{PGPR}+\mathrm{AMF}_{2}$ & $20.12(2.20)^{a, b}$ & $8.91(1.66)$ a,b & $29.04(1.99) \mathrm{a}, \mathrm{b}$ & $97.62(13.60) a, b, c$ & $86.33(1.53) \mathrm{a}, \mathrm{b}$ & $7.50(0.50) \mathrm{a}, \mathrm{b}$ \\
\hline & $\mathrm{PGPR}+\mathrm{AMF}_{1}+\mathrm{Comp}$ & $21.09(2.66)^{\mathrm{a}}$ & $10.78(1.32)^{\mathrm{a}}$ & $31.88(2.07)^{\mathrm{a}}$ & $101.20(18.22) \mathrm{a}, \mathrm{b}$ & $92.00(1.00)^{a}$ & $7.77(0.38)^{a, b}$ \\
\hline & $\mathrm{PGPR}+\mathrm{AMF}_{2}+\mathrm{Comp}$ & $21.44(2.99)^{\mathrm{a}}$ & $10.74(1.30)^{\mathrm{a}}$ & $32.19(2.53)^{\mathrm{a}}$ & $103.40(21.69)^{\mathrm{a}}$ & $91.00(1.00)^{a, b}$ & $8.27(0.25)^{a}$ \\
\hline \multirow{12}{*}{$120 \mathrm{mM}$} & Control & $10.43(0.68)^{d}$ & $3.24(0.46)^{d}$ & $13.67(1.01)^{\mathrm{e}}$ & $55.64(2.46)^{\mathrm{c}}$ & $50.00(2.00)^{\mathrm{h}}$ & $2.60(0.63)^{f}$ \\
\hline & Comp & $13.20(0.15)^{\mathrm{c}}$ & $2.60(0.37)^{d}$ & $15.08(0.28)^{d}$ & $62.60(2.94)^{b}$ & $61.33(1.53) \mathrm{g}$ & $2.97(0.15)^{f}$ \\
\hline & $\mathrm{AMF}_{1}$ & $13.26(0.09)^{\mathrm{c}}$ & $2.88(0.34)^{d}$ & $16.14(0.28)^{d}$ & $64.48(4.82) \mathrm{b}$ & $70.33(1.53)$ de & $4.23(0.40) \mathrm{e}$ \\
\hline & $\mathrm{AMF}_{2}$ & $13.22(0.16)^{\mathrm{c}}$ & $2.49(0.67)^{d}$ & $15.72(0.67)^{d}$ & $64.96(5.12)^{b}$ & $69.00(2.00) \mathrm{e}$ & $4.83(0.35)$ de \\
\hline & PGPR & $13.39(0.18)^{\mathrm{c}}$ & $3.05(0.40)^{d}$ & $16.44(0.29)^{d}$ & $67.80(4.30)^{\mathrm{b}}$ & $60.33(1.53)^{g}$ & $4.77(0.21) \mathrm{d}, \mathrm{e}$ \\
\hline & $\mathrm{AMF}_{1}+\mathrm{Comp}$ & $13.29(0.08)^{b, c}$ & $2.76(0.14)^{d}$ & $16.06(0.08)^{d}$ & $66.66(5.09)^{\mathrm{b}}$ & $74.33(3.06)^{b, c}$ & $5.50(0.50)^{b, c, d}$ \\
\hline & $\mathrm{AMF}_{2}+\mathrm{Comp}$ & $14.58(1.45)^{a, b}$ & $4.31(0.88)^{\mathrm{c}}$ & $16.44(0.59)^{\mathrm{c}}$ & $70.60(3.18)^{b}$ & $75.67(0.58)^{a, b, c}$ & $5.67(0.49)^{b}, c, d$ \\
\hline & PGPR+Comp & $14.53(0.95)^{a, b}$ & $4.50(0.66)^{\mathrm{c}}$ & $19.04(0.31)^{\mathrm{c}}$ & $71.24(2.77)^{b}$ & $64.67(1.53)^{\mathrm{f}}$ & $6.10(0.36)^{b, c}$ \\
\hline & $\mathrm{PGPR}_{+} \mathrm{AMF}_{1}$ & $14.32(0.25)^{a, b, c}$ & $5.61(1.07)^{\mathrm{b}}$ & $19.93(0.91)^{b, c}$ & $67.53(4.10)^{\mathrm{b}}$ & $72.00(2.00)^{c}, \mathrm{~d}, \mathrm{e}$ & $5.17(0.76)^{c, d, e}$ \\
\hline & PGPR+AMF 2 & $14.46(0.27)^{a, b, c}$ & $5.96(1.37)^{\mathrm{b}}$ & $20.42(1.14)^{b}$ & $69.00(4.72)^{\mathrm{b}}$ & $73.00(1.00) \mathrm{c}, \mathrm{d}$ & $6.30(0.82)^{\mathrm{b}}$ \\
\hline & $\mathrm{PGPR}+\mathrm{AMF}_{1}+\mathrm{Comp}$ & $14.57(0.52)^{a, b}$ & $7.50(0.52)^{a}$ & $22.07(0.29)^{a}$ & $79.15(2.80)^{\mathrm{a}}$ & $79.00(1.00)^{\mathrm{a}}$ & $6.43(0.40)^{b}$ \\
\hline & $\mathrm{PGPR}+\mathrm{AMF}_{2}+\mathrm{Comp}$ & $14.73(0.13)^{\mathrm{a}}$ & $7.83(0.46)^{\mathrm{a}}$ & $22.07(0.36)^{a}$ & $80.68(2.38)^{\mathrm{a}}$ & $77.00(1.00)^{a, b}$ & $7.27(0.25)^{a}$ \\
\hline \multirow{12}{*}{$240 \mathrm{mM}$} & Control & $5.66(0.38)^{f}$ & $2.08(0.18)^{\mathrm{e}}$ & $7.74(0.32)^{\mathrm{g}}$ & $47.49(12.56)^{\mathrm{a}}$ & $38.67(0.58)^{\mathrm{f}}$ & $2.13(0.32)^{\mathrm{c}}$ \\
\hline & Comp & $6.71(0.44)^{\mathrm{e}}$ & $3.26(0.13)^{d}$ & $9.98(0.50)^{f}$ & $51.94(12.19)^{\mathrm{a}}$ & $58.00(1.00)^{c, d}$ & $2.47(0.35)^{b, c}$ \\
\hline & $\mathrm{AMF}_{1}$ & $7.03(0.38)$ de & $3.34(0.16)^{d}$ & $10.37(0.47)^{\mathrm{f}}$ & $49.39(0.71)^{\mathrm{a}}$ & $60.00(1.00)^{c, d}$ & $3.70(0.62)^{a}, \mathrm{~b}, \mathrm{c}$ \\
\hline & $\mathrm{AMF}_{2}$ & $7.13(0.37)$ de & $3.47(0.17)^{d}$ & $10.60(0.48)^{\mathrm{f}}$ & $49.57(0.74)^{a}$ & $60.33(2.08)^{\mathrm{c}}$ & $3.83(0.76)^{a}, \mathrm{~b}, \mathrm{c}$ \\
\hline & PGPR & $7.76(0.20)^{\mathrm{c}}$ & $4.34(0.18)^{\mathrm{c}}$ & $12.11(0.75)$ de & $51.94(0.48)^{\mathrm{a}}$ & $52.00(1.00)^{\mathrm{e}}$ & $3.73(0.38)^{a, b, c}$ \\
\hline & $\mathrm{AMF}_{1}+\mathrm{Comp}$ & $7.47(0.13)^{\mathrm{c}, \mathrm{d}}$ & $4.22(0.66)^{\mathrm{c}}$ & $11.69(0.74)^{\mathrm{e}}$ & $51.67(0.49)^{\mathrm{a}}$ & $68.33(1.53)^{\mathrm{b}}$ & $4.17(1.26)^{a, b}$ \\
\hline & $\mathrm{AMF}_{2}+\mathrm{Comp}$ & $7.77(0.27)^{\mathrm{c}}$ & $5.02(0.60)^{b}$ & $12.80(0.69)^{\mathrm{c}, \mathrm{d}, \mathrm{e}}$ & $52.41(0.57)^{a}$ & $69.67(1.15)^{\mathrm{a}, \mathrm{b}}$ & $4.33(0.76)^{\mathrm{a}}$ \\
\hline & PGPR+Comp & $7.93(0.30)^{b, c}$ & $5.27(0.44)^{b}$ & $13.21(0.69)^{c, d}$ & $52.87(0.68)^{a}$ & $60.67(1.53)^{\mathrm{c}}$ & $4.47(0.90)^{\mathrm{a}}$ \\
\hline & $\mathrm{PGPR}+\mathrm{AMF}_{1}$ & $8.03(0.32)^{a, b, c}$ & $5.51(0.27)^{b}$ & $13.54(0.58)^{\mathrm{c}}$ & $53.26(0.43)^{a}$ & $57.33(1.15)^{d}$ & $3.17(0.76)^{a, b, c}$ \\
\hline & PGPR+AMF 2 & $8.12(0.31)^{a, b, c}$ & $5.77(0.37)^{a, b}$ & $13.89(0.68)^{b, c}$ & $54.54(0.42)^{\mathrm{a}}$ & $60.00(1.00)^{c, d}$ & $3.20(0.26)^{a, b, c}$ \\
\hline & $\mathrm{PGPR}+\mathrm{AMF}_{1}+\mathrm{Comp}$ & $8.51(0.41)^{a, b}$ & $6.34(0.49)^{\mathrm{a}}$ & $14.86(0.81)^{a, b}$ & $55.86(0.67)^{a}$ & $72.00(1.00)^{\mathrm{a}}$ & $4.47(0.55)^{\mathrm{a}}$ \\
\hline & $\mathrm{PGPR}+\mathrm{AMF}_{2}+\mathrm{Comp}$ & $8.66(0.41)^{\mathrm{a}}$ & $6.47(0.68)^{a}$ & $15.13(1.09)^{a}$ & $56.43(0.42)^{\mathrm{a}}$ & $71.00(1.00)^{\mathrm{a}}$ & $4.07(0.12)^{a, b}$ \\
\hline
\end{tabular}

Comp: compost; $\mathrm{AMF}_{1}$ : $\mathrm{AMF}$ consortium; $\mathrm{AMF}_{2}$ : $\mathrm{AMF}$ pure strain; PGPR: plant growth promoting rhizobacteria; Chl a: chlorophyll a content; Chl b: chlorophyll b content. Data presented are means (standard deviations), $\mathrm{n}=3$. Different lowercase letters within a column indicate significant differences between the means of the same parameter analyzed at $p<0.05$. 


\subsection{Biofertilizers Boosted Date Palm Antioxidant Enzyme Activities under Salt Stress}

Salt stress significantly increased the SOD, CAT, POD and PPO activities, regardless of whether the plants were treated with biofertilizers or not $(p<0.001$; Figure 4$)$. The SOD activity was significantly enhanced under stressed and non-stressed conditions by the application of all the treatments compared to the control plants $(p<0.001, \mathrm{~F}=1029.92)$. The highest improvement was recorded in plants treated by PGPR $+\mathrm{AMF}_{2}+\mathrm{Comp}$. According to the CAT activity, all applied treatments enhanced this activity than control plants independently of the salt stress level $(p<0.001, \mathrm{~F}=767.85)$, except in the PGPR, $\mathrm{AMF}_{1}+\mathrm{Comp}$ and $\mathrm{AMF}_{2}+$ Comp treatments, did not affect the CAT activity under $0 \mathrm{mM}$ of salinity level. The high enhancement was recorded in the plants submitted to the high salinity level and treated with the PGPR $+\mathrm{AMF}_{1}+\mathrm{Comp}$ and $\mathrm{PGPR}+\mathrm{AMF}_{2}+\mathrm{Comp}$ treatments. The POD activity was significantly enhanced by the application of PGPR bacteria AMF and compost, alone or in the different combinations under whatever salinity level $(p<0.001, \mathrm{~F}=978.06)$. Under $240 \mathrm{mM}$ level, the PGPR $+\mathrm{AMF}_{1}, \mathrm{PGPR}+\mathrm{AMF}_{2}$ and $\mathrm{PGPR}+\mathrm{AMF}_{2}+\mathrm{Comp}$ treatments greatly increased the POD activity by $37 \%, 39 \%$ and $39 \%$ respectively over control plants and the other treatments. For PPO activity, the applied treatments generally increased this enzymatic activity over control plants under stressed conditions (120 and $240 \mathrm{mM})(p<0.001, \mathrm{~F}=930.84)$. A high increment in PPO activity was recorded in plants inoculated with PGPR bacteria and $\mathrm{AMF}_{1}\left(\mathrm{PGPR}+\mathrm{AMF}_{1}\right)$, with enhancements of $170 \%$ and $54 \%$ for120 and $240 \mathrm{mM}$ of NaCl, respectively compared to the controls. However, under non-stressed conditions, only $\mathrm{AMF}_{1}, \mathrm{AMF}_{2}, \mathrm{PGPR}+\mathrm{Comp}, \mathrm{PGPR}+\mathrm{AMF}_{1}, \mathrm{PGPR}+\mathrm{AMF}_{2}, \mathrm{PGPR}+\mathrm{AMF}_{1}+\mathrm{Comp}$ and $\mathrm{PGPR}+\mathrm{AMF}_{2}+\mathrm{Comp}$ treatments increased the $\mathrm{PPO}$ activity compared to the control plants.

\subsection{Biofertilizers Improved Soil Physical and Chemical Traits under Salt Stress}

The physicochemical properties of soil after the experiment reported in Table 5 showed significant effects of the salt stress on the $\mathrm{pH}, \mathrm{EC}, \mathrm{TOC}, \mathrm{OM}$ and available $\mathrm{P}$. The $\mathrm{pH}$ values decreased after the experiment compared to the initial soil value (8.6). However, the application of compost under $120 \mathrm{mM}$ salinity level decreased the $\mathrm{pH}$ to a lower value (7.94). Concerning EC, the application of the biofertilizers increased this parameter under non-stressed conditions, except that one recorded in the case of PGPR $+\mathrm{AMF}_{2}$, which significantly decreased compared to the control. Under stressed conditions (120 and $240 \mathrm{mM}$ ), the EC values were significantly decreased. In the absence of salt stress, the TOC rate was reduced by half in the plants treated by $\mathrm{PGPR}+\mathrm{AMF}_{1}$ and $\mathrm{PGPR}+\mathrm{AMF}_{2}$ compared to the inoculated and non-amended control. The applied biofertilizers significantly enhanced the $\mathrm{OM}$ compared to the control independently to the salinity level. Moreover, the application of compost alone or in different combinations with AMF and/or PGPR bacteria enhanced the amount of OM in the soil. Concerning the available P content in the soil, the application of compost, AMF and PGPR bacteria alone or in different combinations enhanced the P content in the soil. The addition of compost, whether or not it was associated with AMF and/or PGPR, considerably increased the available P content under every salinity level. 

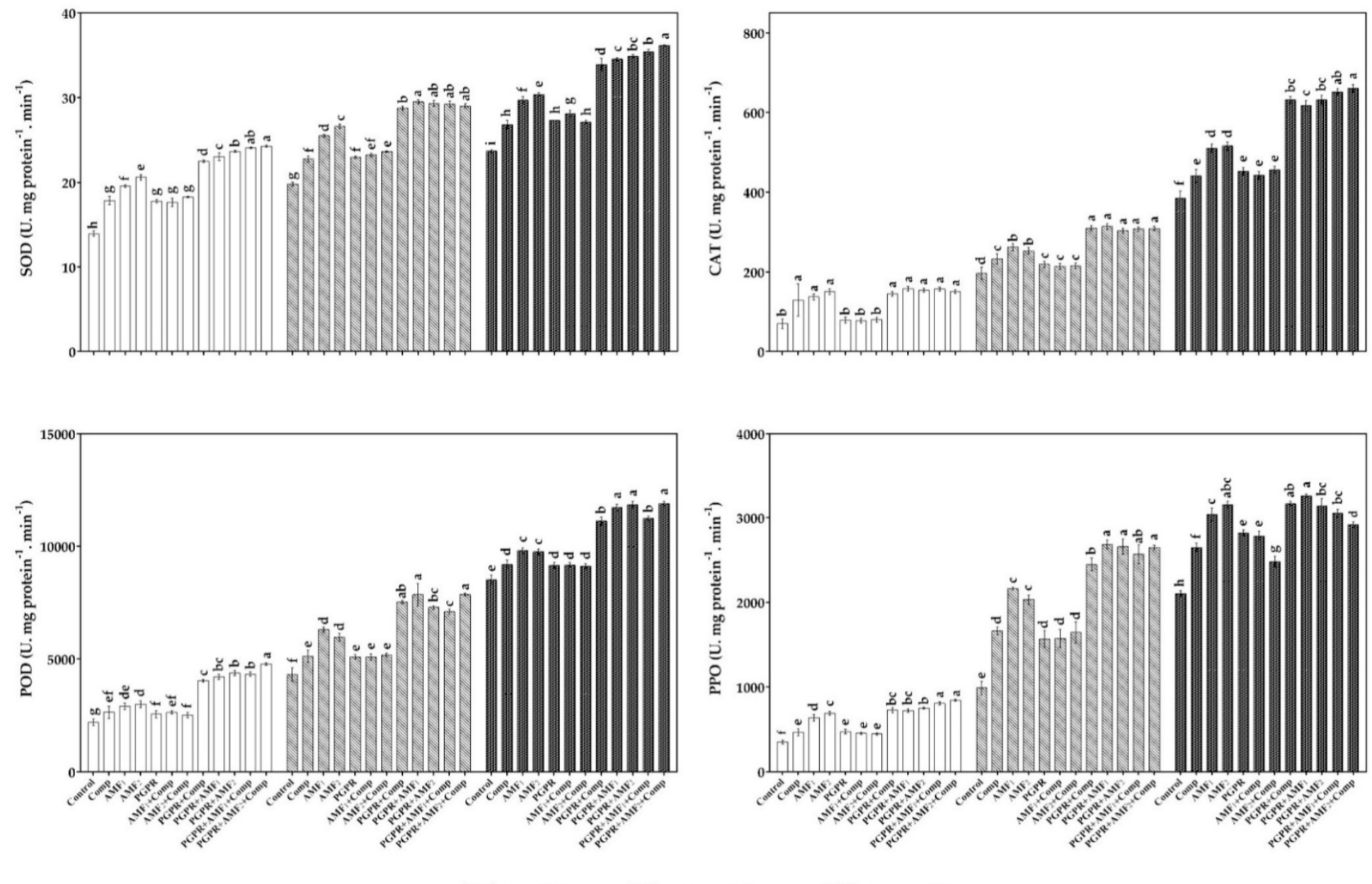

\section{$\square 0 \mathrm{mM} \quad 120 \mathrm{mM}$}

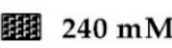

Figure 4. Effects of salt stress and biofertilizers on superoxide dismutase (SOD), catalase (CAT), peroxidase (POD) and polyphenol oxidase (PPO) activities in date palm vitroplants. Comp: compost; $\mathrm{AMF}_{1}$ : $\mathrm{AMF}$ consortium; $\mathrm{AMF}_{2}$ : $\mathrm{AMF}$ pure strain; PGPR plant growth promoting rhizobacteria. Data presented are means \pm standard deviations, $\mathrm{n}=3$. Bars followed by the same letters within the same salt stress level are not significantly different according to Student-Newman-Keuls test $(p<0.05)$. 
Table 5. Effects of biofertilizers on soil physicochemical properties after harvesting the date palm vitroplants.

\begin{tabular}{|c|c|c|c|c|c|c|}
\hline $\mathrm{NaCl}$ & Treatments & $\mathrm{pH}$ & $\mathrm{EC}\left(\mu \mathrm{s} \cdot \mathrm{cm}^{-2}\right)$ & TOC (\%) & OM (\%) & $P_{\text {Olsen }}(\mathrm{ppm})$ \\
\hline \multirow{12}{*}{$0 \mathrm{mM}$} & Control & $8.47(0.08)^{c, d}$ & $334.00(10.00)^{h}$ & $0.50(0.12)^{\mathrm{f}}$ & $0.87(0.21)^{f}$ & $13.68(1.06)^{f}$ \\
\hline & Comp & $8.42(0.03) \mathrm{d}, \mathrm{e}$ & $742.00(12.00)^{\mathrm{e}}$ & $1.47(0.06)^{b}$ & $2.54(0.10)^{b}$ & $162.42(3.32)^{c}$ \\
\hline & $\mathrm{AMF}_{1}$ & $8.60(0.02)^{a, b}$ & $410.00(5.00)^{\mathrm{f}}$ & $1.06(0.06)^{c, d}$ & $1.82(0.10)^{c, d}$ & $38.71(2.03)^{\mathrm{e}}$ \\
\hline & $\mathrm{AMF}_{2}$ & $8.45(0.04)^{c, d}$ & $430.00(5.00)^{f}$ & $1.00(0.01)^{c, d}$ & $1.74(0.02)^{\mathrm{c}, \mathrm{d}}$ & $41.05(1.47)^{\mathrm{e}}$ \\
\hline & PGPR & $8.61(0.02)^{a, b}$ & $387.00(4.00)^{\mathrm{g}}$ & $0.71(0.16)^{\mathrm{e}}$ & $1.23(0.27)^{\mathrm{e}}$ & $55.47(2.60)^{d}$ \\
\hline & $\mathrm{AMF}_{1}+\mathrm{Comp}$ & $8.37(0.01)^{d, e}$ & $1403.00(20.00)^{a}$ & $1.924(0.10)^{\mathrm{a}}$ & $3.32(0.18)^{a}$ & $182.92(8.34)^{a b}$ \\
\hline & $\mathrm{AMF}_{2}+$ Comp & $8.33(0.04) \mathrm{e}^{\mathrm{e}}$ & $1354.00(9.00)^{b}$ & $2.02(0.09)^{a}$ & $3.48(0.15)^{\mathrm{a}}$ & $182.92(8.34)^{a b}$ \\
\hline & PGPR+Comp & $8.13(0.10)^{f}$ & $1057.50(24.50)^{\mathrm{c}}$ & $1.13(0.06)^{c}$ & $1.94(0.10)^{\mathrm{c}}$ & $173.27(4.49)^{b}$ \\
\hline & $\mathrm{PGPR}+\mathrm{AMF}_{1}$ & $8.69(0.03)^{a}$ & $374.00(10.00) \mathrm{g}$ & $0.26(0.10)^{g}$ & $0.45(0.18) \mathrm{g}$ & $61.03(166)^{d}$ \\
\hline & $\mathrm{PGPR}+\mathrm{AMF}_{2}$ & $8.65(0.04)^{\mathrm{a}}$ & $318.50(5.50)^{h}$ & $0.25(0.04) \mathrm{g}$ & $0.43(0.08)^{g}$ & $59.63(1.56)^{d}$ \\
\hline & $\mathrm{PGPR}+\mathrm{AMF}_{1}+$ Comp & $8.53(0.04)^{b, c}$ & $794.00(15.00)^{d}$ & $0.88(0.10)^{\mathrm{d}}$ & $1.52(0.18)^{d}$ & $192.48(11.54)^{\mathrm{a}}$ \\
\hline & $\mathrm{PGPR}+\mathrm{AMF}_{2}+$ Comp & $8.46(0.01)^{c, d}$ & $780.50(1.50)^{\mathrm{d}}$ & $1.06(0.07)^{\mathrm{c}, \mathrm{d}}$ & $1.83(0.13)^{c, d}$ & $187.88(10.75)^{a}$ \\
\hline \multirow{12}{*}{$120 \mathrm{mM}$} & Control & $8.05(0.08)^{\mathrm{e}}$ & $830.00(15.00)^{b}$ & $0.26(0.10)^{\mathrm{e}}$ & $0.45(0.18)^{\mathrm{e}}$ & $11.27(1.09)^{\mathrm{g}}$ \\
\hline & Comp & $7.94(0.01)^{\mathrm{f}}$ & $739.00(14.00)^{\mathrm{c}}$ & $1.09(0.10)^{\mathrm{c}}$ & $1.88(0.18)^{\mathrm{c}}$ & $218.25(5.18)^{a}$ \\
\hline & $\mathrm{AMF}_{1}$ & $8.32(0.05)^{c}$ & $634.50(13.50)^{\mathrm{e}}$ & $0.68(0.10)^{d}$ & $1.17(0.18)^{d}$ & $51.15(1.94)^{\mathrm{e}}$ \\
\hline & $\mathrm{AMF}_{2}$ & $8.31(0.02)^{c}$ & $656.00(9.00) d, e$ & $0.77(0.12)^{d}$ & $1.33(0.20)^{d}$ & $50.65(1.80)^{e}$ \\
\hline & PGPR & $8.56(0.03)^{\mathrm{a}}$ & $820.50(4.5 .)^{b}$ & $0.54(0.12)^{d}$ & $0.93(0.21)^{d}$ & $74.86(1.60)^{d}$ \\
\hline & $\mathrm{AMF}_{1}+$ Comp & $8.38(0.05)^{b, c}$ & $640.00(5.00)$ d,e & $1.20(0.10)^{b, c}$ & $2.06(0.18)^{b, c}$ & $187.40(3.98)^{c}$ \\
\hline & $\mathrm{AMF}_{2}+$ Comp & $8.32(0.05)^{c}$ & $641.50(5.50) \mathrm{d}, \mathrm{e}$ & $1.23(0.12) b, c$ & $2.13(0.21)^{b, c}$ & $187.46(4.33)^{\mathrm{c}}$ \\
\hline & PGPR+Comp & $8.51(0.03)^{a}$ & $598.00(6.00)^{f}$ & $1.20(0.10)^{b, c}$ & $2.06(0.18)^{b, c}$ & $219.65(3.02)^{a}$ \\
\hline & $\mathrm{PGPR}+\mathrm{AMF}_{1}$ & $8.43(0.03)^{b}$ & $899.50(5.50)^{a}$ & $0.57(0.10)^{d}$ & $0.99(0.18)^{d}$ & $39.01(3.30)^{f}$ \\
\hline & $\mathrm{PGPR}+\mathrm{AMF}_{2}$ & $8.41(0.02)^{b}$ & $885.50(10.50)^{\mathrm{a}}$ & $0.75(0.01)^{d}$ & $1.29(0.02)^{d}$ & $50.78(2.95)^{\mathrm{e}}$ \\
\hline & $\mathrm{PGPR}+\mathrm{AMF}_{1}+$ Comp & $8.20(0.01)^{d}$ & $660.00(15.00)^{d}$ & $1.37(0.16)^{a, b}$ & $2.36(0.27)^{a, b}$ & $201.43(3.76)^{b}$ \\
\hline & $\mathrm{PGPR}+\mathrm{AMF}_{2}+\mathrm{Comp}$ & $8.24(0.03)^{d}$ & $653.00(5.00) \mathrm{d}, \mathrm{e}$ & $1.51(0.03)^{\mathrm{a}}$ & $2.61(0.05)^{a}$ & $193.04(6.55)^{c}$ \\
\hline \multirow{7}{*}{$240 \mathrm{mM}$} & Control & $8.15(0.01)^{\mathrm{e}}$ & $1260.00(4.00)^{b}$ & $0.38(0.08)^{\mathrm{e}}$ & $0.65(0.14)^{\mathrm{e}}$ & $10.88(0.46)^{g}$ \\
\hline & Comp & $8.03(0.04)^{\mathrm{f}}$ & $856.50(2.50)^{\mathrm{i}}$ & $1.31(0.04)^{b}$ & $2.26(0.07)^{b}$ & $256.58(6.86)^{a}$ \\
\hline & $\mathrm{AMF}_{1}$ & $8.26(0.01)^{c, d}$ & $1023.50(0.50)^{e}$ & $0.88(0.04)^{\mathrm{c}}$ & $1.52(0.06)^{c}$ & $46.86(1.62)^{\mathrm{f}}$ \\
\hline & $\mathrm{AMF}_{2}$ & $8.20(0.08)^{c, d, e}$ & $992.50(0.50)^{\mathrm{f}}$ & $0.95(0.05)^{c}$ & $1.64(0.09)^{c}$ & $46.25(2.27)^{f}$ \\
\hline & PGPR & $8.47(0.01)^{\mathrm{a}}$ & $1125.00(1.00)^{d}$ & $0.49(0.02)^{d, e}$ & $0.84(0.03)^{d, e}$ & $88.95(2.42)^{\mathrm{e}}$ \\
\hline & $\mathrm{AMF}_{1}+$ Comp & $8.27(0.05)^{c, d}$ & $862.00(3.00)^{\mathrm{i}}$ & $1.30(0.05)^{b}$ & $2.25(0.09)^{b}$ & $241.91(3.56)^{b}$ \\
\hline & $\mathrm{AMF}_{2}+$ Comp & $8.28(0.09)^{\mathrm{c}}$ & $895.50(0.50)^{g}$ & $1.45(0.06)^{a, b}$ & $2.50(0.10)^{a, b}$ & $238.41(2.84)^{b}$ \\
\hline
\end{tabular}


Table 5. Cont.

\begin{tabular}{|c|c|c|c|c|c|c|}
\hline $\mathrm{NaCl}$ & Treatments & $\mathrm{pH}$ & $\mathrm{EC}\left(\mu \mathrm{s} \cdot \mathrm{cm}^{-2}\right)$ & TOC (\%) & OM (\%) & $P_{\text {Olsen }}(\mathrm{ppm})$ \\
\hline & PGPR+Comp & $8.37(0.01)^{b}$ & $992.00(6.00)^{f}$ & $1.43(0.07)^{a, b}$ & $2.46(0.12)^{a, b}$ & $261.34(3.20)^{a}$ \\
\hline & $\mathrm{PGPR}+\mathrm{AMF}_{1}$ & $8.40(0.01)^{b}$ & $1161.50(2.50)^{c}$ & $0.52(0.04)^{d}$ & $0.90(0.06)^{d}$ & $50.48(0.95)^{f}$ \\
\hline & $\mathrm{PGPR}+\mathrm{AMF}_{2}$ & $8.36(0.02)^{b}$ & $1274.00(10)^{a}$ & $0.56(0.03)^{d}$ & $0.97(0.05)^{d}$ & $49.92(3.70)^{f}$ \\
\hline & $\mathrm{PGPR}+\mathrm{AMF}_{1}+$ Comp & $8.18(0.02)^{\mathrm{d}, \mathrm{e}}$ & $891.00(5.00) \mathrm{g}$ & $1.48(0.14)^{\mathrm{a}}$ & $2.55(0.23)^{a}$ & $219.92(1.29)^{\mathrm{C}}$ \\
\hline & $\mathrm{PGPR}+\mathrm{AMF}_{2}+$ Comp & $8.18(0.02) \mathrm{d}, \mathrm{e}$ & $872.00(7.00)^{h}$ & $1.51(0.09)^{\mathrm{a}}$ & $2.60(0.16)^{a}$ & $208.88(3.31)^{\mathrm{d}}$ \\
\hline
\end{tabular}

Comp: compost; $\mathrm{AMF}_{1}$ : AMF consortium; $\mathrm{AMF}_{2}$ : AMF pure strain; PGPR: plant growth promoting rhizobacteria; EC: electrical conductivity; TOC: total organic carbon; OM: organic matter content. Data presented are means (standard deviations), $\mathrm{n}=3$. Different lowercase letters within a column indicate significant differences between the means of the same parameter analyzed at $p<0.05$ 


\subsection{The Principal Component Analysis}

The principal component analysis (PCA) displayed that inoculation treatments (in blue) and variables (in red) were correlated with degrees of variability F1: 56.70\% (Figure 5). The PCA shows that treatments with higher growth parameters (SFW, SDW, RFW, RDW, leaf number and plant height); physiological parameters (Fv/Fm and gs); leaf water potential; photosynthetic pigments; sugar and protein content; and AMF frequency and intensity belong on the right; they correspond to the plants cultivated under non-stressed conditions. Lower records are on the left; they corresponded to the plants submitted to the severe $\mathrm{NaCl}$ dose $(240 \mathrm{mM})$, besides the control plants. On the vertical axis, plants subjected to the intermediate salinity level presented intermediate values.

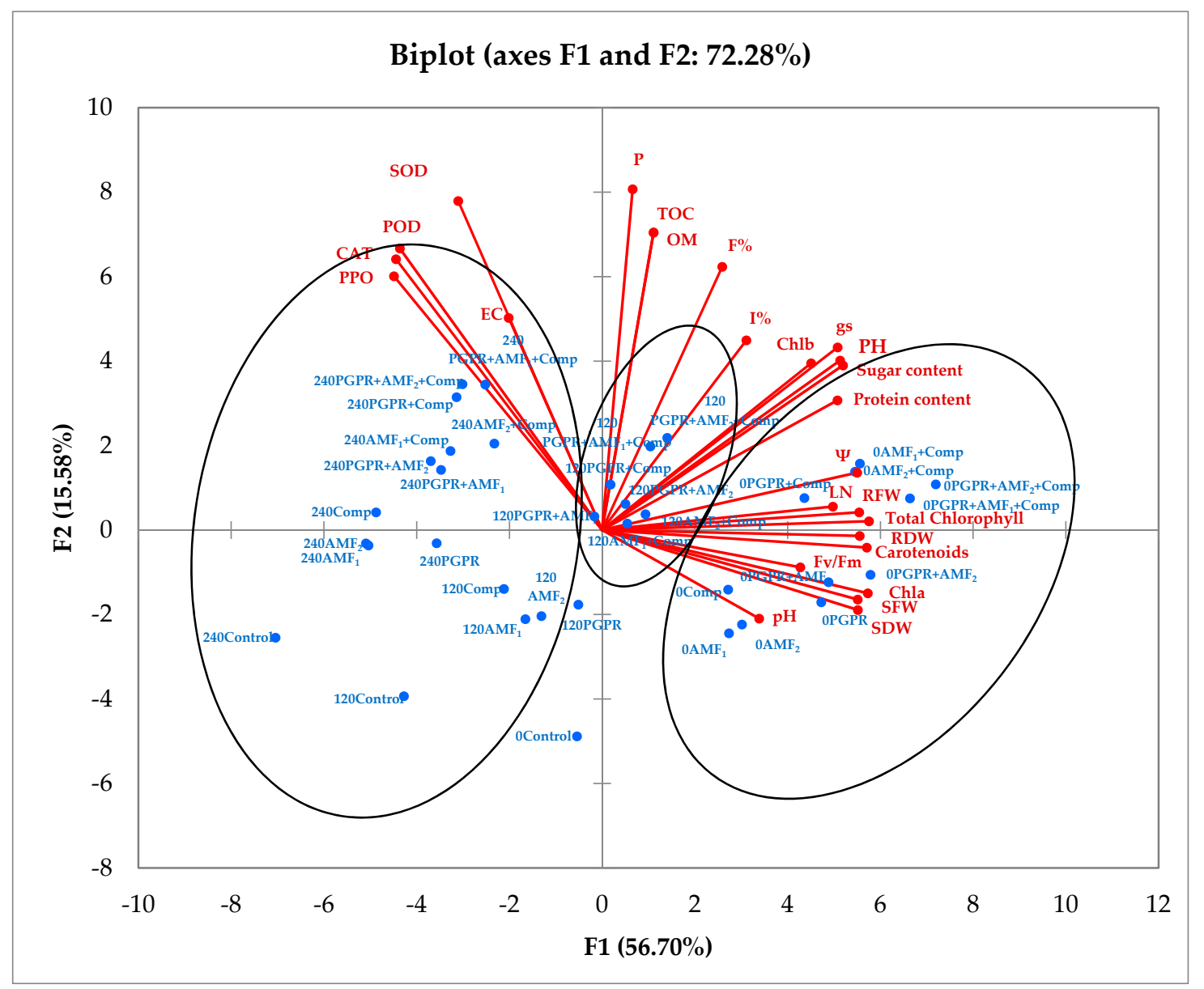

Figure 5. The principal component analysis (PCA), Comp: compost; $\mathrm{AMF}_{1}: \mathrm{AMF}$ consortium; $\mathrm{AMF}_{2}$ : AMF pure strain; PGPR: plant growth promoting rhizobacteria; $\mathrm{PH}$ : plant height; LN: leaf number; SFW: shoot fresh weight; SDW: shoot dry weight; RFW: root fresh weight; RDW: root dry weight; Fv/Fm: chlorophyll fluorescence; gs: gas exchange; $\Psi$ : leaf water potential; F\%: mycorrhizal frequency; I\%: mycorrhizal intensity; Chla: chlorophyll a; Chlb: chlorophyll b; PPO: polyphenoloxidase; POD: peroxidase; CAT: catalase; SOD: superoxidedismutase; EC: electrical conductivity; TOC: total organic carbon; OM: organic matter; P: soil $\mathrm{P}_{\text {olsen }}$.

\section{Discussion}

The potential roles of AMF, PGPR and compost in improving the tolerance of date palm vitroplants to salt stress were investigated. We carried out this work to study the impacts of biofertilizers alone, in double or in triple combination on the morphological, physiological and biochemical parameters of date palm vitroplants exposed to salt stress. 
Our results showed that the dual inoculation of plants with AMF and PGPR further increased root colonization. These results are in accordance with those obtained by Visen et al. [49] and Raklami et al. [50], who found that inoculation with PGPR significantly stimulates AMF colonization of plants compared to non-inoculated plants. However, the AMF colonization of date palm plants was reduced by salt stress, especially at $240 \mathrm{mM} \mathrm{NaCl}$. The same results were reported by Meddich et al. [7], Paymaneh et al. [51] and Ait-El-Mokhtar et al. [6] under salt stress.

In our study, we observed that salinity causes a considerable decrease in crop biomass. Biofertilizer application alone or in combination improved the studied growth parameters plant height; leaf number; and fresh and dry weights of shoots and roots. The best results were obtained when biofertilizers were applied in tripartite combination either in the presence or in the absence of salt stress. Finlay [52] illustrated that in the interactions between plants and biological fertilizers such as AMF, PGPR and compost-the different partners - benefit from this mutualistic association. Several studies have shown that the use of PGPR has a positive effect on the growth and tolerance of plants to salt stress $[53,54]$. Thus, in this study, the increased plant biomass maybe attributed to the growth-promoting mechanisms used by microorganisms such as the production of phytohormones and mineral solubilization. Furthermore, AMF have the ability to improve plant growth by developing external hyphae that can extend the surrounding soil masse [55]. Besides, AMF have been shown to alleviate salt stress by improving nutrient acquisition, especially by reducing the uptake of sodium and chlorine, enhancing water uptake $[8,34,56]$. Moreover, the application of organic amendments to soils such as compost represents a valuable agricultural practice, as it improves plant growth by increasing the availability of nutrients in soils such as phosphorus, calcium, nitrogen and potassium [57]. Beneficial effects of AMF, PGPR and compost on growth responses in plants under salt stress have also been found in alfalfa [34], tomato [58] and corn [59].

Our results showed that salinity reduced physiological parameters such as leaf water potential, stomatal conductance and chlorophyll pigment content. Similar results were reported by Ait-El-Mokhtar et al. [6,8] in date palm and Ben-Laouane et al. [34] in alfalfa. Indeed, salt stress reduces available water to plants and causes leaf stomata closure, which limits the assimilation of $\mathrm{CO}_{2}$ and subsequently the disruption of photosynthetic activity. However, the application of biofertilizers improved the physiological parameters studied under both saline and non-saline conditions. Similarly, several studies have demonstrated that the dual or triple combination of AMF, compost and PGPR has a strong capacity to reduce the negative effects of salt stress on plant growth, by improving photosynthesis and water status $[34,56,60]$. The present study demonstrated that the application of salinity significantly reduced the contents of total chlorophylls, carotenoids and chlorophylls $\mathrm{a}$ and $\mathrm{b}$. This reduction might have been caused by chlorophyll-degrading enzymes, such as chlorophyllases. Similar results were found in maize [61-63], radishes [64] and the date palm [65]. In the same way, Hasheem et al. [66] have shown that organic amendment and AMF reduced the decline in photosynthesis induced by abiotic stress by improving the synthesis of chlorophyll pigments. Similarly, Hidri et al. [67] reported that the inoculation of AMF and PGPR increases plant tolerance to salt stress through higher chlorophyll content and a stronger antioxidant defense system. The synergistic effect of AMF, PGPR and compost might have resulted from the fact that AMF improves the ability of plants to acquire nutrients derived from compost. Indeed, the hyphae of AMF increase the absorption of nutrients such as magnesium, which increases the total chlorophyll content in mycorrhizal plants [68].

Our data indicated that the concentrations of soluble sugars and protein increased during salt stress in treated plants compared to control plants. The better results were recorded when the biofertilizers were applied in combination, especially $\mathrm{PGPR}+\mathrm{AMF}_{1}+\mathrm{Comp}$ and $\mathrm{PGPR}+\mathrm{AMF}_{2}+\mathrm{Comp}$ treatments. Plants can tolerate salt stress by modifying the biochemical responses via improving the biosynthesis of metabolites such as sugars. Copetta et al. [69] observed that the use of AMF and compost improved plant quality by improving their biochemical composition via increases in sugar and protein contents. Previous studies have shown that genes related to sugar metabolism tend to be enriched in plants treated with beneficial microbes under abiotic stress [70]. 
In the present study, SOD, CAT, POD and PPO activities increased under salt stress but this decrease was anticipated by the application of biofertilizers. Indeed, the selected biofertilizers could promote antioxidant enzyme activities as a protective strategy [20]. It is well documented that salt stress increases ROS in plants, resulting in oxidative stress [8,34]. Plants possess several antioxidant mechanisms to protect themselves against ROS. SOD is the first enzyme of defense that catalyzes the transformation of $\mathrm{O}_{2}{ }^{-}$into $\mathrm{H}_{2} \mathrm{O}_{2}$ and $\mathrm{O}_{2}$. APX and CAT act to convert $\mathrm{H}_{2} \mathrm{O}_{2}$ into water and oxygen [71]. Our results showed significant increases in POD and PPO in plants subjected to salt stress and inoculated with PGPR and AMF and/or amended with compost compared to control plants. Several studies suggested that PGPR have the potential to increase tolerance to salinity by improving the stability and plasticity of plant cell membranes by activating the antioxidant defense system. The application of compost and the inoculation with AMF and PGPR might alleviate or decrease RNA disassembly and might enhance the ability of the non-enzymatic antioxidant defense system using soluble proteins [72].

Our study revealed the amelioration of soil physicochemical properties after harvest. Under salt stress the application of biofertilizers, compost mainly increased soil quality, such as $\mathrm{OM}$ and $\mathrm{P}$ content, compared to the controls. After the compost application, the decrease of soil $\mathrm{pH}$ can be attributed to the mineralization of the organic matter and the release of $\mathrm{CO}_{2}$. Soil $\mathrm{pH}$ plays an important role in the mobility and availability of nutrients [73]. In addition, in the absence of salt stress, the TOC rate was reduced by half in pots treated by the bipartite combination of AMF and PGPR compared to the non-inoculated control. Montiel-Rozas et al. [74] showed that the application of organic amendments increased the microbial activity of the soil. Significant increments in the OM and available P, especially with the application of compost alone or in combined use with PGPR or AMF, were noted and resulted from the high content of OM and available P in the compost. Similar results were recorded by Gaiotti et al. [75].

Previous work reported about the role of PGPR in improving the physicochemical properties of soils via several mechanisms, such as the fixation of $\mathrm{N}$; the solubilization of $\mathrm{P}$ and $\mathrm{K}$; and the release of exopolysaccharides and siderophores, which are important for soil stabilization [56,76]. AMF are known to alleviate salt stress by improving soil physiochemical properties via their hyphal networks and the production of glomalin, which was shown to increase soil aggregate stability and consequently soil water potential $[77,78]$.

To summarize, amended and inoculated date palm vitroplants under stressed conditions showed higher growth rates and photosynthesis capacities, improved physiological traits and enhanced oxidative stress tolerance. Furthermore, physicochemical soil properties were improved, highlighting the potential of the selected biofertilizers to alleviate the detrimental effects of salinity stress.

\section{Conclusions}

The exposure of plants to environmental stresses, such as salinity, results in changes in their morphological, physiological and biochemical states. Salt stress caused negative effects, in particular limited plant growth, decreased photosynthesis and a decline in soil physicochemical properties. In our study we showed that AMF, PGPR and compost have the potential to mitigate the negative effects of salt stress on date palm vitroplants by increasing photosynthesis, activating the antioxidant enzymatic system and improving the growth, especially when applied in the tripartite combinations of AMF, PGPR and compost. Therefore, the tested biofertilizers represent a good alternative to be used in salt stress-prone areas to improve agricultural production and at the same time to reduce the use of chemical fertilizers.

Author Contributions: Conceptualization: A.M., M.H., S.S., M.J., H.B.-A. and K.O.; methodology: S.T., A.M., M.H., S.S., M.J., H.B.-A. and K.O.; validation: A.M., M.H., S.S., M.J. and H.B.-A.; formal analysis: S.T., A.-i.T., R.B.-L., M.A.-E.-M., M.A., A.B. and Y.A.-R., writing original draft preparation: S.T., A.-i.T., R.B.-L., M.A.-E.-M., M.A., A.B., M.J. and A.M.; supervision: A.M. and S.S.; project administration: A.M., M.H., S.S., H.B.-A. and K.O.; funding acquisition: S.S., and A.M. All authors have read and agreed to the published version of the manuscript. 
Funding: This work was funded by the r4d project "Application of organic bio-fertilizer technology to improve the sustainability of date palm production and cultivation" with the grant number IZ07Z0_160904 funded by the r4d program, the Swiss Program for Research on Global Issues for Development, a partnership of the Agency for Development and Cooperation and the Swiss National Science Foundation. This work was carried out as part of activities planned by the Tuniso-Moroccan Mixed Laboratories (LMTM) of Plant Physiology and Biotechnology and Climate Change LPBV2C.

Conflicts of Interest: The authors declare that the research was conducted in the absence of any commercial or financial relationships that could be construed as potential conflicts of interest.

\section{References}

1. Gros-Balthazard, M.; Newton, C.; Ivorra, S.; Pintaud, J.-C.; Terral, J.-F. Origines et domestication du palmier dattier (Phoenix dactylifera L.). Rev. Ethnoécologie 2013, 1-15. [CrossRef]

2. FAOSTAT Food and Agriculture Organization of the United Nations Statistics Division. Available online: http://www.fao.org/faostat/en/\#data/QC (accessed on 24 April 2019).

3. Arias, E.; Hodder, A.J.; Oihabi, A. FAO support to date palm development around the world: 70 years of activity. Emirates J. Food Agric. 2016, 28, 1-11. [CrossRef]

4. Meddich, A.; Oufdou, K.; Boutasknit, A.; Raklami, A.; Tahiri, A.; Ben-Laouane, R.; Ait-El-Mokhtar, M.; Anli, M.; Mitsui, T.; Wahbi, S.; et al. Use of organic and biological fertilizers as strategies to improve crop biomass, yields and physicochemical Parameters of soil. In Nutrient Dynamics for Sustainable Crop Production; Springer: Singapore, China, 2020; pp. 247-288. ISBN 9789811386602.

5. Ait-El-Mokhtar, M.; Boutasknit, A.; Ben-Laouane, R.; Anli, M.; El Amerany, F.; Toubali, S.; Lahbouki, S.; Wahbi, S.; Meddich, A. Vulnerability of oasis agriculture to climate change in morocco. In Impacts of Climate Change on Agriculture and Aquaculture; IGI Global: Hershey, PA, USA, 2020; pp. 76-106. ISBN 9781799833437.

6. Ait-El-Mokhtar, M.; Baslam, M.; Ben-Laouane, R.; Anli, M.; Boutasknit, A.; Mitsui, T.; Wahbi, S.; Meddich, A. Alleviation of detrimental effects of salt stress on date palm (Phoenix dactylifera L.) by the application of arbuscular mycorrhizal fungi and/or compost. Front. Sustain. Food Syst. 2020, 4, 131. [CrossRef]

7. Meddich, A.; Ait El Mokhtar, M.; Bourzik, W.; Mitsui, T.; Baslam, M.; Hafi, M. Optimizing growth and tolerance of date palm (Phoenix dactylifera L.) to drought, salinity, and vascular fusarium-induced wilt (Fusarium oxysporum) by application of arbuscular mycorrhizal fungi (AMF). In Root Biology; Giri, B., Prasad, R., Varma, A., Eds.; Springer: New York, NY, USA, 2018; pp. 239-258. ISBN 978-3-319-75909-8.

8. Ait-El-Mokhtar, M.; Laouane, R.B.; Anli, M.; Boutasknit, A.; Wahbi, S.; Meddich, A. Use of mycorrhizal fungi in improving tolerance of the date palm (Phoenix dactylifera L.) seedlings to salt stress. Sci. Hortic. 2019, 253, 429-438. [CrossRef]

9. Zhang, Y.C.; Wang, P.; Wu, Q.H.; Zou, Y.N.; Bao, Q.; Wu, Q.S. Arbuscular mycorrhizas improve plant growth and soil structure in trifoliate orange under salt stress. Arch. Agron. Soil Sci. 2017, 63, 491-500. [CrossRef]

10. Gill, S.S.; Tuteja, N. Reactive oxygen species and antioxidant machinery in abiotic stress tolerance in crop plants. Plant Physiol. Biochem. 2010, 48, 909-930. [CrossRef] [PubMed]

11. Asgher, M.; Per, T.S.; Masood, A.; Fatma, M.; Freschi, L.; Corpas, F.J.; Khan, N.A. Nitric oxide signaling and its crosstalk with other plant growth regulators in plant responses to abiotic stress. Environ. Sci. Pollut. Res. 2017, 24, 2273-2285. [CrossRef] [PubMed]

12. Centritto, M.; Lauteri, M.; Monteverdi, M.C.; Serraj, R. Leaf gas exchange, carbon isotope discrimination, and grain yield in contrasting rice genotypes subjected to water deficits during the reproductive stage. J. Exp. Bot. 2009, 60, 2325-2339. [CrossRef] [PubMed]

13. Gamalero, E.; Favale, N.; Bona, E.; Novello, G.; Cesaro, P.; Massa, N.; Glick, B.R.; Orozco-Mosqueda, M.D.; Berta, G.; Lingua, G. Screening of bacterial endophytes able to promote plant growth and increase salinity tolerance. Appl. Sci. 2020, 10, 5767. [CrossRef]

14. Awasthi, J.P.; Chandra, T.; Mishra, S.; Parmar, S.; Shaw, B.P.; Nilawe, P.D.; Chauhan, N.K.; Sahoo, S.; Panda, S.K. Identification and characterization of drought responsive miRNAs in a drought tolerant upland rice cultivar KMJ 1-12-3. Plant Physiol. Biochem. 2019, 137, 62-74. [CrossRef]

15. Baslam, M.; Qaddoury, A.; Goicoechea, N. Role of native and exotic mycorrhizal symbiosis to develop morphological, physiological and biochemical responses coping with water drought of date palm. Phoenix Dactylifera Trees 2014, 28, 161-172. [CrossRef] 
16. Liu, J.; Chu, J.; Ma, C.; Jiang, Y.; Ma, Y.; Xiong, J.; Cheng, Z.-M. Overexpression of an ABA-dependent grapevine bZIP transcription factor, VvABF2, enhances osmotic stress in Arabidopsis. Plant Cell Rep. 2019, 38, 587-596. [CrossRef] [PubMed]

17. Gori, A.; Ferrini, F.; Marzano, M.C.; Tattini, M.; Centritto, M.; Baratto, M.C.; Pogni, R.; Brunetti, C. Characterisation and antioxidant activity of crude extract and polyphenolic rich fractions from $C$. incanus leaves. Int. J. Mol. Sci. 2016, 17, 1344. [CrossRef] [PubMed]

18. Begum, N.; Qin, C.; Ahanger, M.A.; Raza, S.; Khan, M.I.; Ashraf, M.; Ahmed, N.; Zhang, L. Role ofarbuscular mycorrhizal fungi in plant growth regulation: Implications in abiotic stress tolerance. Front. Plant Sci. 2019, 10, 1-15. [CrossRef]

19. Evelin, H.; Devi, T.S.; Gupta, S.; Kapoor, R. Mitigation of salinity stress in plants by arbuscular mycorrhizal symbiosis: Current understanding and new challenges. Front. Plant Sci. 2019, 10, 470. [CrossRef]

20. Wu, N.; Li, Z.; Wu, F.; Tang, M. Comparative photochemistry activity and antioxidant responses in male and female Populus cathayana cuttings inoculated with arbuscular mycorrhizal fungi under salt. Sci. Rep. 2016, 6, 1-15. [CrossRef]

21. Ahmad, P.; Jamsheed, S.; Hameed, A.; Rasool, S.; Sharma, I.; Azooz, M.M.; Hasanuzzaman, M. Drought Stress Induced Oxidative Damage and Antioxidants in Plants; Elsevier Inc.: Oxford, UK, 2014; ISBN 9780127999630.

22. Schneider, K.D.; Thiessen Martens, J.R.; Zvomuya, F.; Reid, D.K.; Fraser, T.D.; Lynch, D.H.; O’Halloran, I.P.; Wilson, H.F. Options for improved phosphorus cycling and use in agriculture at the field and regional scales. J. Environ. Qual. 2019, 48, 1247-1264. [CrossRef]

23. Al-Karaki, G.; McMichael, B.; Zak, J. Field response of wheat to arbuscular mycorrhizal fungi and drought stress. Mycorrhiza 2004, 14, 263-269. [CrossRef]

24. Meddich, A.; Jaiti, F.; Bourzik, W.; El Asli, A.; Hafidi, M. Use of mycorrhizal fungi as a strategy for improving the drought tolerance in date palm (Phoenix dactylifera). Sci. Hortic. 2015, 192, 468-474. [CrossRef]

25. Boutasknit, A.; Baslam, M.; Ait-El-Mokhtar, M.; Anli, M.; Ben-Laouane, R.; Douira, A.; El Modafar, C.; Mitsui, T.; Wahbi, S.; Meddich, A. Arbuscular mycorrhizal fungi mediate drought tolerance and recovery in two contrasting carob (Ceratonia siliqua L.) ecotypes by regulating stomatal, water relations, and (In)organic adjustments. Plants 2020, 9, 80. [CrossRef]

26. Boutaj, H.; Meddich, A.; Chakhchar, A.; Wahbi, S.; El Alaoui-Talibi, Z.; Douira, A.; Filali-Maltouf, A.; El Modafar, C. Arbuscular mycorrhizal fungi improve mineral nutrition and tolerance of olive tree to Verticillium wilt. Arch. Phytopathol. Plant Prot. 2020, 53, 673-689. [CrossRef]

27. Boutaj, H.; Chakhchar, A.; Meddich, A.; Wahbi, S.; El Alaoui-Talibi, Z.; Douira, A.; Filali-Maltouf, A.; El Modafar, C. Bioprotection of olive tree from Verticillium wilt by autochthonous endomycorrhizal fungi. J. Plant Dis. Prot. 2020, 127, 349-357. [CrossRef]

28. Spaepen, S.; Vanderleyden, J.; Remans, R. Indole-3-acetic acid in microbial and microorganism-plant signaling. FEMS Microbiol. Rev. 2007, 31, 425-448. [CrossRef] [PubMed]

29. Dixon, R.; Kahn, D. Genetic regulation of biological nitrogen fixation. Nat. Rev. Microbiol. 2004, 2, 621-631. [CrossRef]

30. Anli, M.; Symanczik, S.; El Abbassi, A.; Ait-El-Mokhtar, M.; Boutasknit, A.; Ben-Laouane, R.; Toubali, S.; Baslam, M.; Mäder, P.; Hafidi, M.; et al. Use of arbuscular mycorrhizal fungus Rhizoglomus irregulare and compost to improve growth and physiological responses of Phoenix dactylifera "Boufgouss". Plant Biosyst. An. Int. J. Deal. Asp. Plant Biol. 2020, 1-14. [CrossRef]

31. Boutasknit, A.; Anli, M.; Tahiri, A.; Raklami, A.; Ait-El-Mokhtar, M.; Ben-Laouane, R.; Ait Rahou, Y.; Boutaj, H.; Oufdou, K.; Wahbi, S.; et al. Potential effect of horse manure-green waste and olive pomace-green waste composts on physiology and yield of garlic (Allium sativum L.) and soil fertility. Gesunde Pflanz. 2020, 72, 285-295. [CrossRef]

32. Raklami, A.; El Gharmali, A.; Ait Rahou, Y.; Oufdou, K.; Meddich, A. Compost and mycorrhizae application as a technique to alleviate $\mathrm{Cd}$ and $\mathrm{Zn}$ stress in Medicago sativa. Int. J. Phytoremediat. 2020, 1-12. [CrossRef]

33. Raklami, A.; Tahiri, A.; Bechtaoui, N.; Abdelhay, E.G.; Pajuelo, E.; Baslam, M.; Meddich, A.; Oufdou, K. Restoring the plant productivity of heavy metal-contaminated soil using phosphate sludge, marble waste, and beneficial microorganisms. J. Environ. Sci. 2020, 99, 210-221. [CrossRef]

34. Ben-Laouane, R.; Meddich, A.; Bechtaoui, N.; Oufdou, K.; Wahbi, S. Effects of arbuscular mycorrhizal fungi and rhizobia symbiosis on the tolerance of Medicago sativa to salt stress. Gesunde Pflanz. 2019, 71, 135-146. [CrossRef] 
35. Meddich, A.; Elouaqoudi, F.; Khadra, A.; Bourzik, W. Valorization of green and industrial waste by composting process. J. Rev. Compos. Adv. Mater. 2016, 26, 451-469.

36. Trouvelot, A.; Kough, J.L.; Gianinazzi, V. Mesure de taux de mycorhization VA d'un système radiculaire. Recherche de méthodes d'estimation ayant une signification fonctionnelle. In Physiological and Genetic Aspects of Mycorhizical; Gianinazzi, P., Gianinazzi, S., Eds.; INRA: Paris, France, 1986; pp. 217-221.

37. Phillips, J.M.; Hayman, D.S. Improved procedures for clearing roots and staining parasitic and vesicular-arbuscular mycorrhizal fungi for rapid assessment of infection. Trans. Br. Mycol. Soc. 1970, 55, 158-161. [CrossRef]

38. Harley, P.C.; Loreto, F.; Di Marco, G.; Sharkey, T.D. Theoretical considerations when estimating the mesophyll conductance to $\mathrm{CO}_{2}$ flux by analysis of the response of photosynthesis to $\mathrm{CO}_{2}$. Plant Physiol. 1992, 98, 1429-1436. [CrossRef] [PubMed]

39. Scholander, P.F.; Hammel, H.T.; Bradstreet, E.D.; Hemmingsen, E.A. Sap pressure in vascular plants: Negative hydrostatic pressure can be measured in plants. Science 1965, 148, 339-346. [CrossRef] [PubMed]

40. Lichtenthaler, H.K. Chlorophylls and carotenoids: Pigments of photosynthetic biomembranes. Meth. Enzymol. 1987, 148, 350-382.

41. Dubois, M.; Gilles, K.A.; Hamilton, J.K.; Rebers, P.A.; Smith, F. Colorimetric method for determination of sugars and related substances. Anal. Chem. 1956, 28, 350-356. [CrossRef]

42. Bradford, M.M. A rapid and sensitive method for the quantitation of microgram quantities of protein utilizing the principle of protein-dye binding. Anal. Biochem. 1976, 72, 248-254. [CrossRef]

43. Duarte, B.; Goessling, J.W.; Marques, J.C.; Caçador, I. Ecophysiological constraints of Aster tripolium under extreme thermal events impacts: Merging biophysical, biochemical and genetic insights. Plant Physiol. Biochem. 2015, 97, 217-228. [CrossRef]

44. Beyer, W.F.; Fridovich, I. Assaying for superoxide dismutase activity: Some large consequences of minor changes in conditions. Anal. Biochem. 1987, 161, 559-566. [CrossRef]

45. Bergmeyer, H.; Bernt, E. Determination of glucose with glucose-oxidase and peroxidase. In Methods of Enzymatic Analysis; Bergmeyer, H., Ed.; Elsevier: Amsterdam, The Netherlands, 1974; pp. 123-129.

46. Moore, B.M.; Flurkey, W.H. Sodium dodecyl sulfate activation of a plant polyphenoloxidase. J. Biol. Chem. 1990, 265, 4982-4989.

47. Aubert, G. Méthodes D'analyses des Sols; Centre National de documentation Pédagogique, Centre Régional de Documentation Pédagogique: Marseille, France, 1978; p. 191.

48. Olsen, S.; Sommers, L. Methods of soil analysis. Part 2. Chemical and microbiological properties of phosphorus. ASA Monograp. 1982, 9, 403-430.

49. Visen, A.; Bohra, M.; Singh, P.N.; Srivastava, P.C.; Kumar, S.; Sharma, A.K.; Chakraborty, B. Two pseudomonad strains facilitate AMF mycorrhization of litchi (Litchi chinensis Sonn.) and improving phosphorus uptake. Rhizosphere 2017, 3, 196-202. [CrossRef]

50. Raklami, A.; Bechtaoui, N.; Tahiri, A.; Anli, M.; Meddich, A.; Oufdou, K. Use of rhizobacteria and mycorrhizae consortium in the open field as a strategy for improving crop nutrition, productivity and soil fertility. Front. Microbiol. 2019, 10, 1-11. [CrossRef] [PubMed]

51. Paymaneh, Z.; Sarcheshmehpour, M.; Bukovská, P.; Jansa, J. Could indigenous arbuscular mycorrhizal communities be used to improve tolerance of pistachio to salinity and/or drought? Symbiosis 2019, 79, 269-283. [CrossRef]

52. Finlay, R.D. Ecological aspects of mycorrhizal symbiosis: With special emphasis on the functional diversity of interactions involving the extraradical mycelium. J. Exp. Bot. 2008, 59, 1115-1126. [CrossRef] [PubMed]

53. Orhan, F. Alleviation of salt stress by halotolerant and halophilic plant growth-promoting bacteria in wheat (Triticum aestivum). Braz. J. Microbiol. 2016, 47, 621-627. [CrossRef]

54. Antoun, H. Plant-growth-promoting rhizobacteria. In Brenner's Encyclopedia of Genetics; Elsevier: Amsterdam, The Netherlands, 2013; pp. 353-355. ISBN 9780080961569.

55. Giovannetti, M.; Fortuna, P.; Citernesi, A.S.; Morini, S.; Nuti, M.P. The occurrence of anastomosis formation and nuclear exchange in intact arbuscular mycorrhizal networks. New Phytol. 2001, 151, 717-724. [CrossRef]

56. Bharti, N.; Barnawal, D.; Wasnik, K.; Tewari, S.K.; Kalra, A. Co-inoculation of Dietzia natronolimnaea and Glomus intraradices with vermicompost positively influences Ocimum basilicum growth and resident microbial community structure in salt affected low fertility soils. Appl. Soil Ecol. 2016, 100, 211-225. [CrossRef] 
57. Mbarki, S.; Labidi, N.; Mahmoudi, H.; Jedidi, N.; Abdelly, C. Contrasting effects of municipal compost on alfalfa growth in clay and in sandy soils: N, P, K, content and heavy metal toxicity. Bioresour. Technol. 2008, 99, 6745-6750. [CrossRef]

58. Hajiboland, R.; Aliasgharzad, N.; Laiegh, S.F.; Poschenrieder, C. Colonization with arbuscular mycorrhizal fungi improves salinity tolerance of tomato (Solanum lycopersicum L.) plants. Plant Soil 2010, 331, 313-327. [CrossRef]

59. Sheng, M.; Tang, M.; Zhang, F.; Huang, Y. Influence of arbuscular mycorrhiza on organic solutes in maize leaves under salt stress. Mycorrhiza 2011, 21, 423-430. [CrossRef]

60. Krishnamoorthy, R.; Kim, K.; Subramanian, P.; Senthilkumar, M.; Anandham, R.; Sa, T. Arbuscular mycorrhizal fungi and associated bacteria isolated from salt-affected soil enhances the tolerance of maize to salinity in coastal reclamation soil. Agric. Ecosyst. Environ. 2016, 231, 233-239. [CrossRef]

61. Abdel Latef, A.A.H.; Mostofa, M.G.; Rahman, M.M.; Abdel-Farid, I.B.; Tran, L.-S.P. Extracts from yeast and carrot roots enhance maize performance under seawater-induced salt stress by altering physio-biochemical characteristics of stressed plants. J. Plant Growth Regul. 2019, 38, 966-979. [CrossRef]

62. Abdel Latef, A.; Kordrostami, M.; Zakir, A.; Zaki, H.; Saleh, O. Eustress with $\mathrm{H}_{2} \mathrm{O}_{2}$ facilitates plant growth by improving tolerance to salt stress in two wheat cultivars. Plants 2019, 8, 303. [CrossRef]

63. Abdel Latef, A.A.H.; Abu Alhmad, M.F.; Kordrostami, M.; Abo-Baker, A.B.A.E.; Zakir, A. Inoculation with Azospirillum lipoferum or Azotobacter chroococcum reinforces maize growth by improving physiological activities under saline conditions. J. Plant Growth Regul. 2020, 39, 1293-1306. [CrossRef]

64. Jamil, M.; Lee, K.J.; Kim, J.M.; Kim, H.-S.; Rha, E.S. Salinity reduced growth PS2 photochemistry and chlorophyll content in radish. Sci. Agric. 2007, 64, 111-118. [CrossRef]

65. Al Kharusi, L.; Sunkar, R.; Al-Yahyai, R.; Yaish, M.W. Comparative water relations of two contrasting date palm genotypes under salinity. Int. J. Agron. 2019, 2019, 4262013. [CrossRef]

66. Hashem, A.; Kumar, A.; Al-Dbass, A.M.; Alqarawi, A.A.; Al-Arjani, A.B.F.; Singh, G.; Farooq, M.; Abd_Allah, E.F. Arbuscular mycorrhizal fungi and biochar improves drought tolerance in chickpea. Saudi J. Biol. Sci. 2019, 26, 614-624. [CrossRef]

67. Hidri, R.; Barea, J.M.; Mahmoud, O.M.; Abdelly, C.; Azcón, R. Impact of microbial inoculation on biomass accumulation by Sulla carnosa provenances, and in regulating nutrition, physiological and antioxidant activities of this species under non-saline and saline conditions. J. Plant Physiol. 2016, 201, 28-41. [CrossRef]

68. Chen, S.; Zhao, H.; Zou, C.; Li, Y.; Chen, Y.; Wang, Z.; Jiang, Y.; Liu, A.; Zhao, P.; Wang, M. Combined inoculation with multiple arbuscular mycorrhizal fungi improves growth, nutrient uptake and photosynthesis in cucumber seedlings. Front. Microbiol. 2017, 8, 1-11. [CrossRef]

69. Copetta, A.; Bardi, L.; Bertolone, E.; Berta, G. Fruit production and quality of tomato plants (Solanum lycopersicum L.) are affected by green compost and arbuscular mycorrhizal fungi. Plant Biosyst. Int. J. Deal. Asp. Plant Biol. 2011, 145, 106-115. [CrossRef]

70. Ahanger, M.A.; Tyagi, S.R.; Wani, M.R.; Ahmad, P. Drought tolerance: Role of organic osmolytes, growth regulators, and mineral nutrients. In Physiological Mechanisms and Adaptation Strategies in Plants Under Changing Environment; Springer: New York, NY, USA, 2014; Volume 1, pp. 1-376. ISBN 9781461485919.

71. Mittler, R. Oxidative stress, antioxidants and stress tolerance. Trends Plant Sci. 2002, 7, 405-410. [CrossRef]

72. Abbaspour, H.; Saeidi-Sar, S.; Afshari, H.; Abdel-Wahhab, M.A. Tolerance of mycorrhiza infected pistachio (Pistacia vera L.) seedling to drought stress under glasshouse conditions. J. Plant Physiol. 2012, 169, 704-709. [CrossRef] [PubMed]

73. Ben Achiba, W.; Gabteni, N.; Lakhdar, A.; Du Laing, G.; Verloo, M.; Jedidi, N.; Gallali, T. Effects of 5-year application of municipal solid waste compost on the distribution and mobility of heavy metals in a Tunisian calcareous soil. Agric. Ecosyst. Environ. 2009, 130, 156-163. [CrossRef]

74. del Mar Montiel-Rozas, M.; López-García, Á.; Kjøller, R.; Madejón, E.; Rosendahl, S. Organic amendments increase phylogenetic diversity of arbuscular mycorrhizal fungi in acid soil contaminated by trace elements. Mycorrhiza 2016, 26, 575-585. [CrossRef]

75. Gaiotti, F.; Marcuzzo, P.; Belfiore, N.; Lovat, L.; Fornasier, F.; Tomasi, D.; Bel, N.; Lovat, L.; Fornasier, F.; Tomasi, D. Influence of compost addition on soil properties, root growth and vine performances of Vitis vinifera cv Cabernet sauvignon. Sci. Hortic. 2017, 225, 88-95. [CrossRef] 
76. Aalipour, H.; Nikbakht, A.; Etemadi, N.; Rejali, F.; Soleimani, M. Biochemical response and interactions between arbuscular mycorrhizal fungi and plant growth promoting rhizobacteria during establishment and stimulating growth of Arizona cypress (Cupressus arizonica G.) under drought stress. Sci. Hortic. 2020, 261, 108923. [CrossRef]

77. Garcia, C.L.; Dattamudi, S.; Chanda, S.; Jayachandran, K. Effect of salinity stress and microbial inoculations on glomalin production and plant growth parameters of snap bean (Phaseolus vulgaris). Agronomy 2019, 9, 545. [CrossRef]

78. Ben-Laouane, R.; Baslam, M.; Ait-El-Mokhtar, M.; Anli, M.; Boutasknit, A.; Ait-Rahou, Y.; Toubali, S.; Mitsui, T.; Oufdou, K.; Wahbi, S. Potential of native arbuscular mycorrhizal fungi, rhizobia, and/or green compost as alfalfa (Medicago sativa) enhancers under salinity. Microorganisms 2020, 8, 1695. [CrossRef]

Publisher's Note: MDPI stays neutral with regard to jurisdictional claims in published maps and institutional affiliations.

(C) 2020 by the authors. Licensee MDPI, Basel, Switzerland. This article is an open access article distributed under the terms and conditions of the Creative Commons Attribution (CC BY) license (http://creativecommons.org/licenses/by/4.0/). 